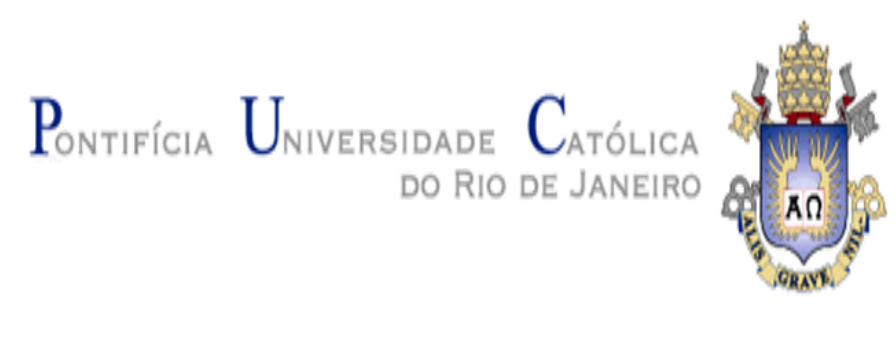

Leandro Novaes da Silva

\title{
What is monotony? Understanding the quality of life in my English language classes
}

\section{DEPARTAMENTO DE LETRAS}

Curso de Especialização em Língua Inglesa 


\section{cce \\ COORDENAÇÃo \\ CENTRAL DE \\ EXTENSÃO \\ DEPARTAMENTO DE LETRAS}

Curso de Especialização em Língua Inglesa

What is monotony? Understanding the quality of life in my English language classes

Leandro Novaes da Silva

Prof ${ }^{a}$ Maria Isabel Azevedo Cunha

Orientadora

Departamento de Letras - PUC-Rio 


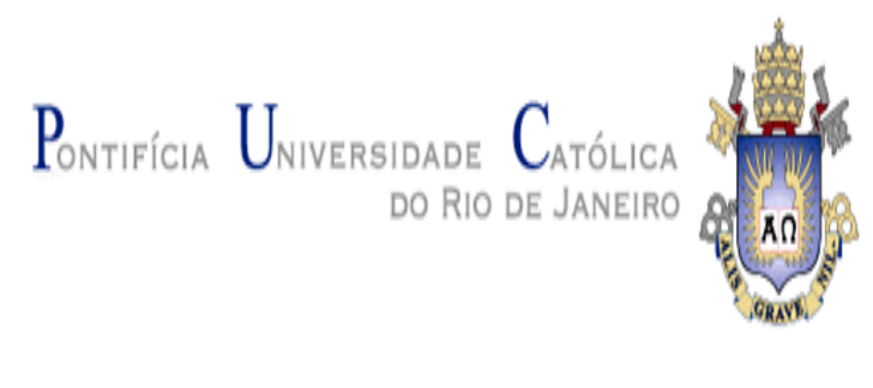

Leandro Novaes da Silva

\section{What is monotony? Understanding the quality of life in my English language classes}

Monografia apresentada ao Programa de Pós-Graduação em Letras da PUC-Rio como requisito parcial para obtenção do título de Especialista em Língua Inglesa.

Prof $^{a}$ Maria Isabel Azevedo Cunha

Orientadora

Departamento de Letras - PUC-Rio 
Since ancient times no one has heard, no ear has perceived, no eye has seen any God besides you, who acts on behalf of those who wait for him.

Isaiah 64: 4 


\section{ACKNOWLEDGEMENTS}

After dedicating myself to the development of this research, it is time to thank all those who contributed somehow to the accomplishment of such a dream. It would be naïve to believe that it was not a hard task, but I attempted to overcome all the obstacles.

Firstly, I thank God for blessing me in a way that I could take advantage of all wisdom throughout the realization of this work. My godmother Elisabete Martins was also responsible for my decision of being a teacher and that is why I also thank her for being my inspiration. Mere words cannot express how important my father Robson Roberto was to make my dream come true. I am grateful for all his support.

In addition, I express all my gratitude to my adviser Maria Isabel Azevedo Cunha not only for her patience and availability but also for all her wise ideas that contributed for the success of my work. I could never forget all teachers and professors such as Inés K. Miller who raised awareness and exposed different views that enriched my academic and professional background. They were definitely incredible.

I thank all my classmates who took part in my academic life. By interacting and sharing ideas, they gave a great contribution to this hard process as well. Furthermore, my experience as a university student was definitely pleasant and entertaining because of them.

Finally, I am thankful to my friends, relatives and everyone who loves me. This work was possible because you bet on me. I still believe that I can fly even higher that is why I hope you keep on praying and cheering for me. I believe the key for success is dedication in combination with hard work. 


\begin{abstract}
Silva, Leandro Novaes; Cunha, Maria Isabel Azevedo. (Advisor). What is monotony? Understanding the quality of life in my English language classes. Rio de Janeiro, 2019, p. 73. Monograph - Departamento de Letras, Pontifícia Universidade Católica do Rio de Janeiro.
\end{abstract}

The fact that some of my classes seemed to be monotonous motivated me to carry out this research project. I wonder about the reasons why teachers attempt to avoid monotonous classes without trying to understand the phenomenon together with their students. I believe this work may contribute to develop critical individuals and promote collaboration and interaction among classroom practitioners. According to Dick Allwright (2001), learning is all about relationship. Therefore, monotony cannot simply be ignored as if we were struggling for solutions or changes. In fact, teachers should work for understanding and perhaps try to find some basis to take appropriate actions. For these reasons, I chose a qualitative approach based on Exploratory Practice in order to investigate students' perspective in relation to monotonous classes. They are encouraged to express their feelings and thoughts by means of a PEPA whereby we will interact and reflect about quality of life in the classroom. Students also wrote narratives about their academic experience which may reflect their beliefs and motivations so as to come to understandings during the investigation process.

Key words: Monotony; Motivation; Exploratory Practice; Learning Process 


\section{RESUMO}

Silva, Leandro Novaes; Cunha, Maria Isabel Azevedo. (Orientadora). O que é monotonia? Entendendo a qualidade de vida em minhas aulas de inglês. Rio de Janeiro, 2019, p. 73. Monografia - Departamento de Letras, Pontifícia Universidade Católica do Rio de Janeiro.

$\mathrm{O}$ fato de algumas das minhas aulas parecerem monótonas me motivou a realizar este projeto de pesquisa. Eu me questionei quanto às razões pelas quais os professores tentam evitar aulas monótonas sem tentar se quer entender o fenômeno junto com seus alunos. Eu acredito que este trabalho pode contribuir para desenvolver indivíduos críticos e promover colaboração e interação entre os participantes em sala de aula. De acordo com Dick Allwright (2001), aprender é fundamentalmente baseado em relacionamento. Portanto, a monotonia não pode simplesmente ser ignorada como se estivéssemos lutando por soluções ou mudanças. De fato, os professores devem trabalhar para entender e talvez encontrar alguma base para tomar as ações apropriadas. Por essas razões, optei por uma abordagem qualitativa baseada na Prática Exploratória, a fim de investigar a perspectiva dos alunos em relação à aulas monótonas. Eles são encorajados a expressar seus sentimentos e pensamentos por meio de um APPE pela qual interagimos e refletimos sobre qualidade de vida em sala de aula. Os alunos também escreveram narrativas sobre suas experiências acadêmicas as quais podem refletir suas crenças e motivações, de modo a chegar a entendimentos durante o processo de investigação.

Palavras-chave: Monotonia; Motivação; Prática Exploratória; Aprendizagem 


\section{CONTENTS}

1 Introduction 9

2 Literature Review 13

2.1 What perspectives might we have when we deliver our 13 classes?

2.2 What is Applied Linguistics and its domains?

2.3 What is Exploratory Practice? What is its relevance for coming to understandings about monotony?

2.4 How motivated are we practitioners? How important is motivation when the issue is learning a second language? Is there any relation between monotony and motivation in the learning process?

3 Methodology and Data Generation 29

3.1 Research Project 29

3.2 Generating understandings 32

4 Discussing theory and practice through data analysis 41

4.1 Understanding quality of life in the classroom 41

5 Discussion 55

6 Final thoughts $\quad 60$

7 References 64

8 Appendices 66 


\section{1 - INTRODUCTION}

I decided to carry out this research project for two main reasons. First, I have observed the great effort that we teachers make to avoid or even prevent monotonous classes and the persistent obsession with motivation as if it could lead to the ideal class. Second, this research may help classroom practitioners, teachers and students develop critical thinking and mutual understanding when it comes to the quality of life in the English classroom.

I have been working as an English teacher since 2009. So far, I have had great opportunities to be in contact with different students and teachers whose beliefs differ completely concerning teaching and the notion of the "ideal class". Since then, I believed that motivation was an essential pro-active element which could lead to the "ideal class".

In 2013, I got a promotion and became pedagogic coordinator at the same English course where I had been teaching all these years. Since I have become responsible for training all teachers of my branch, my view in relation to monotony inside the classroom may have been affected by orientation given by the language course pedagogical department. Its methods, techniques, procedures and ways of teaching had been working well back then so there was no need to change or reflect upon. I may have been inclined to share such point of view looking for the most effective way of delivering my classes and expressing my view to the teachers in the course. I used to believe that monotony only had to do with the lack of teachers' dynamism or technical procedures in a classroom or the lack of students' participation and interaction in class, due to a teacher's incapability for elaborating an appropriate lesson plan and delivering an interesting English class. However, although I believed that motivating students and instructing teachers to act in the same way was a priority, I realized I still had to deal with monotony in my own classroom. Soon, I started to question what was going on in my teachers' and in my own classes. "Why are some of my classes monotonous?" was a cause for concern, and I believed that such concern was not an isolated or an individual query of a particular English teacher. For these reasons, I decided to carry out an investigation and also try to understand other questions that may come out such as "What is monotony?", "What classes are affected?", "Are all my classes 
monotonous?", "Are there moments of monotony in my classes?", "Who is affected by monotony?" and "How does it affect lessons and learning?".

I decided to survey the issue "monotony" by investigating my students' views on the topic. I believed they had different perspectives in relation to their English classes, since they had been through different experiences along their lives as students. As, their perspective might differ according to their realities and needs, this could determine their expectations about classes. Likewise, students may appreciate classes in which they exercise their creativity in a process of co-construction of knowledge, but there are students who may not like to participate. I started this work believing that monotony really existed, but it might not affect the learning process because it was possible for students to learn English despite attending a monotonous class and that teachers could master techniques in order to avoid monotony, while delivering their classes. However, in my effort to understand the quality of life of my classes or even prove my points of view and beliefs throughout this investigation, I started deconstructing some ideas and questioning the existence of monotony.

In order to study my concern about monotony in the classroom, I could have studied other teachers' classes and their responsibilities concerning successful classes. This study could have been about the unpredictability of the English classes, an interesting issue for classroom research practitioners, especially if they do not expect to find formulas to teach. Globalization and the development of technology could be another aspect to study within the topic of monotony as they have contributed to give rise to a new generation of students who are tremendously influenced by the fast circulation of information and the idea that the use of technological devices could optimize the learning process.

All the previous aspects may be interesting for future researches. I tried to come to understandings in relation to my puzzle when it comes to monotonous classes throughout this work and it contributed to make me question my own beliefs.

I started my post-graduation course full of anxieties and hoping to contribute somehow to improve the quality of life in the classroom concerning the oppression that teachers suffer to follow methodological patterns. For me, teacher's autonomy was central for success during the teaching/learning process, but I came to realize that I also used to have some traditional beliefs 
concerning "the ideal class". The specialization course as well as the relationship with my students during my investigation helped me to reflect about my practices, since I was not used to problematize some of my traditional perceptions in relation to "language proficiency", "the best method", "the control of the learning process", "learners' motivation" and so on. I have been learning how to prioritize the quality of life through the experience with my students in the classroom, instead of dwelling on the quality of my work. I used to be a student-teacher who viewed my specialization course as an opportunity to learn different methods or useful activities which may help with the engagement of my students as if the learning process was a product (MORAES BEZERRA, MILLER, CUNHA, 2007). However, I was not yet aware of the fact that the mere command of teaching techniques could not ensure the control of students nor even the quality of life in the classroom. The present work is the result of my experience, someone who could reflect about his own conflicts, deconstruct his beliefs and rethink his role as an English teacher.

I decided to divide the report of my investigation into 5 different sections. In the first one, I will provide a brief historical and theoretical background aiming at the understanding of my puzzle by approaching issues like monotony and the teaching/learning process, in the light of Applied linguistics and Exploratory Practice. In the second section, I will describe the methodological procedures and the data generating process, which followed a qualitative approach and the principles of Exploratory Practice. In the third section, I analyze the data taking into consideration the theoretical background previously discussed. In the fourth section, I will show my understandings after a deep investigative experience which may have affected my own beliefs.

At the end of this work, I am not the same individual who started writing it. The relationship with my students together with the experience acquired as a young researcher made me question some beliefs I used to have. In a post-method era, it is still possible to find individuals who dwell on efficiency, concrete results and absolute solutions for problems (KUMARAVADIVELU, 1994 apud MILLER, 2012, p. 334). Viewing myself as a practitioner researcher and a teacher who will be learning throughout his life, Exploratory Practice contributed to make me live a "positive" professional identity crisis (MILLER, 2001) by which I could understand that the individual 
who dares to teach may never cease to learn. 


\section{2- LITERATURE REVIEW}

This section aims at presenting some theoretical background which can contribute to the understanding of the issues to be investigated.

\section{1 - WHAT PERSPECTIVES MIGHT WE HAVE WHEN WE DELIEVER OUR CLASSES?}

According to the Oxford Advanced Learner's Dictionary (1995), the etymology of the word "monotony", shows its sense of "wearisome, tiresome". From the Latin, monotonns, and from the Greek, monotónos, the word is literally related to "sound", "sameness of tone or pitch"; "want of variety in cadence or inflection". However, in a figurative and transferred meaning, the word is associated with "wearisome sameness of effect"; "tedious recurrence of the same object, actions and so on"; "lack of interesting variety in occupation, scenery, literary style and so on" (OXFORD, 1995, p. 790). Thus, monotony may be viewed as a situation in which something stays the same and is therefore boring.

Concerning teaching, I would like to briefly highlight here and now how teachers have viewed their pedagogical duties and how they were influenced or convinced to adopt some traditional roles. Teachers have taken traditional roles where they represent the absolute authority in the classroom and are responsible for transmitting knowledge. On the other hand, students are viewed as "blank slates" and are supposed to follow their teachers' instructions in order to become competent individuals (LARSEN-FREEMAN, 2000). Although it is still possible to find classes in which the roles are still traditional, with teachers who dwell on following conservative principles and try to increase efficiency (ALLWRIGHT \& HANKS, 2009), there is a tendency to see different attitudes concerning how to deliver the classes conscientiously and meaningfully.

Monotonous classes have to do with the interaction between teachers and students, but classes also involve other social, cultural and personal aspects which transpose the sphere of the classroom. Monotony is worth being investigated, since it is a phenomenon which has everything to do with life in the language classroom.

Interest in languages and language teaching has a long history, and we 
can trace this back at least as far as the Ancient Greeks, where both Plato and Aristotle contributed to the design of a curriculum beginning with good writing (grammar), then moving to effective discourse (rhetoric) and culminating in the development of dialectics to promote a philosophical approach to life (HOWATT, 1999, 618 apud SCHMITT \& CELCE-MURCIA, 2002, 3). However, there was no attention to learners' opinions in such a remote period (LARSEN-FREEMAN, 2000).

In the seventeenth century, there were several attempts to standardize language through prescriptivism, which reflected a new pattern of thinking. The Age of Reason was trying to bring order to everything so there was an attempt to tame the variability in the English language. Locke argued for better use of language that could put an end to disputes. If the definition of words could be agreed and misunderstanding avoided, peace would naturally follow according to him. Jonathan Swift found a model in classical languages, Latin and Greek, believing languages had survived because they never changed. Latin was viewed as a sacred language and a classical model for other languages. Swift attempted to take control of English and put an end to changes, so in 1712 he proposed the foundation of an academy for correcting and improving the English tongue. English should be fixed forever and aristocracy would be replaced. Samuel Johnson wrote the first English dictionary that quickly became the unquestioned authority on the meanings of English words (HOWATT, 1999, 618 apud SCHMITT \& CELCE-MURCIA, 2002, 3). In his period, changing was still for the worse, but Johnson was honest to say that no dictionary could protect language nor even preserve it from corruption and decay. Individuals were worried about the creation of norms and rules in this period so that the roles inside the classroom may have reflected the influential moment that society had been facing.

In such a prescriptivism-oriented society, second languages were usually taught by the "Grammar-translation method", which had been in use since the late eighteenth century. At one time it was called Classical Method since it was first used in the teaching of the classical languages, Latin and Greek. According to Larsen-Freeman (2000, p. 11), this method was used for the purpose of helping students read and appreciate foreign language literature and also become more familiar with the grammar of their native language, through the 
study of the grammar of the target language. According to Schmitt and CelceMurcia (2002, p. 4) one of the main problems of the method was that it focused on the ability to analyze language, and not the ability to use it, apart from the fact that the emphasis on reading and writing did little to promote an ability to communicate orally in the target language.

As a reaction to the Classical Method, the Direct method became popular in the beginning of the twentieth century, specially due to its goal of instruction which was how to use a foreign language to communicate. No translation was allowed and meaning was supposed to be conveyed directly in the target language. The Direct Method also had its own problems such as the fact that teachers were required to be highly proficient in the target language which was not always possible. It also mimicked native language learning and it did not take in consideration the differences between the target language and the native language acquisition and other problems. In the 1970's and 1980's, however, an approach seemed to come as a reaction to the Direct Method. Bringing radical "new" ideas, the Natural Approach proposed that an adult learner could repeat the route to proficiency of the native-speaking child. The idea was that learning would take place without explanation or grading, and without correction of errors, but simply by exposure to "meaningful input" (COOK, 2003, p. 34-35). Directly or indirectly, the notion of communicative competence has been very widely drawn upon in all areas of Applied linguistics. In first-language education, an area addressed by Dell Hymes, it was invoked to justify a shift away from developing only mechanical language skills towards a more rounded capacity to communicate, studies in Applied Linguistics concerning the teaching of English as a foreign language, which contributed to the emergence of a far durable new movement, the Communicative Approach. It emerged at roughly the same time as the development of the Natural Approach and its aim was to develop learners' capacity to use the language effectively.

The focus of Communicative Language Teaching was primarily and necessarily social, concerned as it was with the goal of successful communication. In contrast, the natural approach was essentially psychological, based upon the idea, derived from first-language acquisition studies, that attention to meaning would somehow trigger the natural cognitive development of the language system (COOK, 2003, p.36) 
Students' needs and feelings started being taken into account through these approaches, but in such period there was still an attempt to control what happened inside the classroom and "an obsession" for improving the quality of teachers' work in order to make the learning process meaningful and effective for the learner. Thus, by means of good lesson plans and meaningful and entertaining activities, classes were supposed to be varied and successful.

With the passing of time, a behavioristic view emerged and the working class became protagonist in the development of a nation. In other words, the mechanization of life by means of habit formation or routines so as to increase the production became predominant. It is possible to affirm that the classroom may have reflected such mechanization of life and it has to do with the concern for "control" and its relationship to the notion of planning.

In a Capitalistic world, there might be a need for homogeneity, perhaps because disciplined beings can supposedly produce more in an effective way. Problems are everywhere in the world so that individuals should act in a practical way. They should be able to deal with all problems and obstacles in a way that solutions and conclusions can be achieved as soon as possible. This setting may have contributed to the development of methods based upon structural linguistics and behavioral psychology. Diane Larsen-Freeman discusses the main aspects of the Audio-Lingual Method in her work Techniques and Principles in Language Teaching which reinforces such ideas.

It was thought that the way to acquire the sentence patterns of the target language was through conditioning-helping learners to respond correctly to stimuli through shaping and reinforcement. Learners could overcome the habits of their native language and form the new habits required to be target language speakers. (LARSEN-FREEMAN, 2000, p.35-52)

All these aspects may be seen as a result of the prescriptive/descriptive parallelism. "Practice makes perfect" may sum up the predominant way of understanding the teaching/learning process whereby students should learn by imitating and reproducing the teacher's model when it comes to the AudioLingual Method. Nowadays, it is still possible to figure out some traits from these periods in which individuals were concerned about standards, patterns and 
universalization. Some teachers still treat students as if they were "blank slates" and as if contesting the teachers' instructions would represent a risk for the learning process. Some students still expect translation from an English class, believing that it is the appropriate way of learning the target language. These aspects may have come from a period in which rules could not be transgressed and teacher's orders should be followed as though they would assure the learning process. Individuals were extremely concerned about the language and little attention was given to individuals' thoughts, feelings, cultural beliefs and wishes. Although, nowadays changes have taken place, there is still a need for discussing the students' feelings, thoughts and beliefs, caring more about students' role as protagonists when it comes to the teaching/learning process. However, there are beliefs concerning how classes should be delivered and, as a result, good teaching is still associated to the teachers' ability to control what happens inside the classroom or to follow methodological principles. I confess I was a teacher whose aim was to make my students appreciate my classes, since I believed the use of dynamic activities could motivate them and facilitate their learning process. However, I soon learned that delivering classes may not be like following a script as if the view we have in relation to our classes was always the same. If a student views our class as monotonous, it may not be monotonous for me nor even for other students because classes are not like formulas.

\subsection{WHAT IS APPLIED LINGUISTICS AND ITS DOMAINS ?}

Applied Linguistics is a field whose purpose was primarily meant to solve real-world language-based problems. In order to do this, the field draws upon Linguistics, but not exclusively, according to Kaplan and Grabe (1992, p. 3). Because Applied Linguistics is concerned with the uses of language, it has been heavily identified with language teaching.

Although, it is Applied Linguistics, uniquely, that offers unified solutions to these higher-level conceptual problems in language teaching, it is not solely in language teaching that Applied Linguistics contributes. (STREVENS, 1992 apud KAPLAN \& GRABE, 1992, p. 15) 
According to Peter Strevens (2002, p. 25), the desire to seek a unified theory expressed within some theoretical positions in Linguistics is modeled on Physics, on the belief that the universe can be fully explained in terms of a small number of forces and the rules that govern their interaction. It might have influenced different individuals to deal with the teaching and learning process as if it was a formula. They may have attempted to create the best method taking in consideration what they believed could fulfill their students' needs. However, the concept of social construction provided an appropriate counterbalance for Applied Linguistics. The issue is whether the fundamental laws of physics apply to all events in nature, without exception; in other words, in which case the whole history of the universe is, in principle, "knowable" and its future predictable, or whether some events are by their essence disorganized, chaotic, and thus unpredictable. The work for controlling what happens inside the classroom reflects specialists' obsession in our society with increased "efficiency" or "effectiveness". According to Schmitt and Celce-Murcia (2002, p. 11), sociocultural theory suggests that in order to understand the human mind, one must look at these two endowments: the "sociocultural" (the interpersonal interface between a person and his or her environment) and the "biological" (the intrapersonal mechanism and processes belonging to that person) in an integrated manner. Considering either one individually will inevitably result in an incomplete, and thus inaccurate, representation. For it is only through social interaction with others that humans develop their language and cognition. It goes along with bakhtinian thoughts, since all language interaction is co-constructed with others. Language is not the product of one individual acting alone.

In a contemporary world, there might be a need to reinvent the social life and rethink the way of producing knowledge, doing research to construct social life while trying to understand it (MOITA LOPES, 2006, p.85). Thus, contemporary applied linguists are more concerned about new theories based upon new ways to understand such social life. There should be a new perspective, which questions hegemonic standards, universalization and an occidentalized view of the world. Nowadays, we are living in a society in which knowledge is co-constructed. When individuals interact, they may negotiate different meanings and develop mutual understandings (ALLWRIGHT, 2001; 
MILLER, 2010). According to Miller (2013), when Allwright, in his paper Six Promising Directions for Applied Linguistics, formulates six promising directions for Applied Linguistics, the author is aligned with Moita Lopes (2006). Miller (2013) considers that classroom life is reinvented by means of Exploratory Practice when teachers and students are viewed as practitioners, concerning the teaching/learning process, as well as intellectual individuals who are able to transform their realities. Exploratory Practice reinvents classroom life and ways of producing knowledge in them, as Allwright acknowledges the professional capacity of teacher and students to produce knowledge about their experiences. Allwright makes an urgent claim for Applied Linguistics to value teachers as those who are able to theorize about their local and situated puzzles. Allwright also views the possibility of students working together with their teachers to understand more deeply the life they coconstruct daily in and outside their classrooms.

According to Dick Allwright (2003), by the beginning of the twentieth century, there was an attempt to create methods which could offer principled solutions to all conceivable classroom problems directly or indirectly related to the learning of the target language. Allwright (2003, p. 4) also mentions "they were intended to determine what should happen in the classroom, and to determine thereby the learning that resulted". He pointed that these aspects had to do with a different perspective concerning the issues of planning and of controlling and that is why he (2003, p. 4) affirms "the inappropriateness of trying to plan in advance precisely what should happen in the classroom". For Allwright, several problems may come from this perspective, specially the fact that the classroom is not viewed as a dynamic social situation, but a static mechanical one, under the total and exclusive control of the adopted course book which provides all instructions for teachers, as if the class were a simple factory machine. Thus, by taking classes as something predictable, it may lead to an interpretation of an education in which "good teaching" causes "good learning”. In one of his texts, Allwright (2006, p. 11 apud GIEVE \& MILLER) mentions the different views in relation to the role of applied linguists, language teaching and learning and Language studies in Applied Linguistics and its influence on the creation of methods or approaches and the development of beliefs concerning classroom life "in the 1950's and through to 
the 1960's the job of applied linguists was seen as one of doing the sort of research that would enable applied linguists to tell language teachers what to do for the best for their learners". Allwright also explains that the failure of experiments for methodological comparisons in the mid- and late 1960's to get definite results (and thus serve the above prescriptive aim) "prompted a switch to a descriptive approach to a pedagogical research". According to him, "the problem of the comparisons research had been a failure to adequately describe the teaching that actually happened during the experiments" (ALLWRIGHT, 2006, p. 12). Another way of looking at the shift from prescription to description and then to understanding, as Allwright defends is:

to think of it more generally as a move from a simplistic way of looking at the world of Applied linguistics (for example, thinking, universalistically and causality, that there ought to be just one best method for language teaching, for all languages, for all learners, for all teachers, and for all time), towards a recognition of the essential and irreducible complexity of the phenomenon of classroom language learning and teaching. (ALLWRIGHT, 2006, p.13 apud GIEVE \& MILLER)

Although there are some conservative teachers who dwell on traditional and prescriptive practices and keep on applying what seems to be working in their classes, teachers could be open-minded at least to try to understand their practices. In a prescriptive world, there is almost no space to reflect about student's individuality, but it would be naïve to believe that maintaining the same repertoire of classroom behavior, only because it seemed to have worked in the past, can effectively and certainly fit the current learners.

As an English teacher and a coordinator, I used to think that monotonous classes always existed and that they could be avoided by means of a good lesson plan or the realization of dynamic classes. Throughout my specialization course in English language and my investigation about monotonous classes, I could read and share ideas which contributed to question my way of thinking about monotony since the belief we have of monotonous classes may be subjective. The view individuals have in relation to their classes is relative and the learning process may not depend on the obsessive use of dynamics or effective and meaningful lesson plans as if they could determine 
the quality of our work. This thinking goes along with Allwright when he says the following words in relation to teaching and learning:

An alternative take on this is to say that the productivity of our learning opportunities may depend less on the quality of the work that goes into them than to the quality of classroom life in which they arise. But this still accepts that the ultimate aim is short-term productivity - teaching efficiency. (ALLWRIGHT, 2006, p.14 in GIEVE \& MILLER)

There are students who can learn despite experiencing what may be considered as monotonous classes, specially because little attention is sometimes given to individuals' feelings, in a society that tends to prioritize cognitive aspects when in fact affective aspects are important in the teaching/learning process (TAVARES, 2014). Is it really advantageous to work for controlling what happens in the classroom, even if it does not assure learning? There are teachers who are aware of the unpredictability of classes and admit that students should be seen as human beings and respected when it comes to their personal, social and cultural beliefs. Theoretically speaking it may make total sense to some of them, but in practice monotony or any other classroom phenomenon will keep on being disregarded if teachers continue to worry with content or prioritize knowledge and cognitive aspects of language and disregard the individuality of their students (local understandings and affective aspects).

\section{3 - WHAT IS EXPLORATORY PRACTICE? WHAT IS ITS RELEVANCE FOR COMING TO UNDERSTANDINGS ABOUT MONOTONY?}

Exploratory Practice is a form of practitioner research in which learners as well as teachers are encouraged to investigate their own teaching/leaning practices, while currently practicing the target language. It was originated in the early 1990's, when Dick Allwright, together with teachers and educators, sought better ways of understanding what was going on in the classroom. They perceived they could integrate language learning and teaching with reflection and research itself (HANKS, 2017). Working to understand is essential when it comes to Exploratory Practice. Teachers and students can intensify their 
reflection and focus on taking action for understanding. Dick Allwright attempted to reaffirm the teachers' and students' right to discuss the life in the classroom and encouraged them to reflect about their practices, performance and relationship without struggling to find solutions and arrive at immediate conclusions. Allwright draws attention to another distinguishing feature of Exploratory Practice:

Here it will have to suffice to draw attention to another of the chief distinguishing features of Exploratory Practice: the deliberate exploitation of standard classroom language learning and teaching activities as the means for collecting data on what happens in the classroom, preferably making at the same time a direct contribution to the learning, certainly without lessening in any way the value of lessons as language learning lessons, and all for the explicit purpose of developing understanding of what is happening in the classroom. (ALLWRIGHT, 2001, p.120)

Exploratory Practice may be viewed as an alternative to understanding what is happening in the classroom. By monitoring it with a critical view and reflecting on what has been observed, some "puzzles" may be defined and explored, thus contributing to better understanding of why everything went as it did. When observing teachers, Dick Allwright noticed their attempts to solve problems all the time instead of trying to understand what was happening, before taking any precipitate decision. Instead of working for immediate solutions or worrying more about the quality of work, teachers and students as classroom practitioners can promote mutual understandings and highlight the quality of life in the classroom. Sometimes we can find teachers just acting instinctively keeping activities that seem to be working in the classroom and sometimes abandoning what they believe is not working. However, it seems to be senseless to simply know whether or not an idea or an activity works when there is no work or effort to understand why. For more than one decade Allwright has been working to develop a critical view of classroom members, to prioritize the quality of life in the classroom by encouraging teachers to be aware of their power to transform the working environment and to encourage all participants to get involved in the process of working for understanding instead of struggling for solutions and prescriptive conclusions. Allwright reinforces such ideas in his work Monitoring in which he says: 
It is not sufficient to merely know that something did or not go well. Without some understanding of why it went as it did I will have no sound basis for either deciding to repeat the idea, to adapt it, or to abandon it. (ALLWRIGHT, 1996)

Allwright (1996) also affirms that "teaching" is what is done when teachers want somebody else to learn something and "monitoring" is, by contrast, what should be done when teachers want to learn about what is happening while they are doing the teaching. Monitoring has everything to do with Exploratory Practice since it is one of its main distinguishing features.

In addition, Exploratory Practice would like to help educate critical individuals who think, reflect and share ideas concerning any event or incident in or out of the classroom. It may be viewed as a process of raising awareness of the participants in a way that they can interact and understand the quality of life in their teaching and learning environment. It is not a mere process of collecting data, otherwise it could lack in legitimacy again struggling for precipitate solutions and conclusions.

It is much easier to ignore what is going on and simply resort to the familiar repertoire of classroom behavior that has sustained teachers in the past without attempting to understand the phenomenon, according to Allwright (2003). Monotony is generally related to the lack of variety and for this reason pedagogical departments of language institutes tend to dwell on activities which may work as tools for teachers to grab their students' attention and avoid monotonous classes. It reflects a traditional tendency to planning for control, when, in fact, teachers can be plannig to understand. Again, the focus is not only on the language class but also how they are delivered and how they are understood by the students. Allwright argues against Skinner's behavioristic approach:

Firstly, I would argue that we can now see that Skinner was quite unjustified to claim, in human affairs, that all we needed was the ability to predict and to control. He considered understanding to be an irrelevance, of no value to the improvement of the human condition (see his Walden II, 1948), but time has reinstated understanding, partly because a useful degree of prediction and control have proved impossible to obtain in human affairs (with the possible 
exception of some cases of the treatment of pathological behavior), partly because prediction and control have unavoidable totalitarian overtones that are not socially acceptable, and largely because the social sciences have increasingly revealed the extreme complexity of human behavior, leading us to an abandonment of the simplemindedness of the cause and effect relationships necessary to Skinner's prediction and control conception of human behavior. (ALLWRIGHT, 2003, p. 5)

Exploratory Practice may contribute to involve and encourage the members of classrooms to expose their beliefs about their classes and reflect upon the quality of life in the classroom, instead of simply trying to control the teachers' practices and predict in advance the learning results. Consequently, it may be possible to understand somehow the impact of what is considered as monotonous classes when it comes to the teaching/learning process. Any student may have had an experience in relation to such classes and they may have learned the content successfully or not. R. C. Gardner (1979) argues that motivation is the primary determinant of target language proficiency. He considers the level of motivation to be a reflex of how individual learners define themselves in ethical terms. In other words, learning process is only possible if the learner possesses some degree of motivation. However, by reading Miller (2013), I realized that my "obsession" for motivating my students or conceptualizing their motivation was a traditional belief I had been keeping without much reflection upon it. I did not feel frustrated when I had such an "epiphanic perception". Instead, I remembered a work by Deborah Cameron (1995, p. 9) in which she talks about verbal hygiene. By means of this work, I learned how hard it is to get rid of a normative posture, even for linguists who are supposed to describe the language. Conservative and hierarchical forces in our society tend to value what is traditional and undermine subtle changes. According to Cameron, when we invest time and effort learning how to write in accordance with a variety of prescriptions, we will not easily be convinced that rules are not necessary or desirable because admitting that the rules are arbitrary is like undermining our success of mastering them. We are today who we are due to the different experiences we have lived throughout our lives. Individuals may not remember what they speak, but they remember what they feel. Both cognitive aspects and affective 
aspects are relevant for the learning process (TAVARES, 2014, p. 28-41). In the following section, there will be a discussion about how Gardner managed to divide motivation into two general orientations and how it is related to Exploratory Practice when it comes to Dick Allwright's concern about the power of learners' veto.

\section{4 - HOW MOTIVATED ARE WE PRACTITIONERS? HOW} IMPORTANT IS MOTIVATION WHEN THE ISSUE IS LEARNING A SECOND LANGUAGE? IS THERE ANY RELATION BETWEEN MONOTONY AND MOTIVATION IN THE LEARNING PROCESS?

Before the beginning of my research project, I used to think that monotony was a problem to be avoided and the only way to get rid of it was a dynamic lesson plan. According to the Pedagogical Department of the language course where I worked, there was an instruction to promote fun for the learners and make the learning process meaningful for them. I confess that I do not totally disagree with some of their principles. As a coordinator, I was responsible for preparing teachers to follow the course methodology and assure the quality of their classes by making them follow a pattern with the excuse that the franchising system has everything to do with following standards and that the franchiser is the model for the franchisees. However, the difficulty in predicting what happens in classes made me question myself despite the method being applied and also the fact that changes should come after understandings. The following ideas by Dick Allwright may have contributed to this understanding:

The point I am trying to make here is that the decision as to whether or not change is desirable and possible can only be made, logically, after a serious effort has been made to understand the situation in which change may be held to be both desirable and possible. (ALLWRIGHT, 2001, p.121)

For this reason, I have questioned my way of thinking when it comes to monotony or any other phenomenon which may take place inside the classroom. Every event or phenomenon matters if it is related to the quality of life in the classroom. Moreover, I developed my own reflection that the success of students' learning process may depend primarily on their level of motivation 
integrated with the new knowledge being shared and conveyed in interaction or socialization with the previous knowledge already acquired. However, I realized that I could not be so deterministic generalizing my reflection about the success of students' learning process. We are never the same after an interaction because learning is a process which makes individuals exchange knowledge so as to revise new ideas, thoughts and beliefs. In fact, we need to understand the quality of motivation of our students and students need to try to understand the quality of their motivation as well. Students' motivation, as I have mentioned before, is important to the students and teachers also. The teacher needs to know if s/he wants to get closer to what the students want in terms of learning or in terms of life. Moreover, students should also understand their teachers' motivation and the course motivation. Mutual understanding and integration are required in order to keep a pleasant relationship and develop a better perception of the quality of life in the classroom.

By reading Nada Al Rifai ${ }^{\mathrm{a}}$ 's work Attitude, motivation, and difficulties involved in learning the English language and factors that affect motivation in learning it, I could understand that Al Rifai (2010) was reaffirming motivation as a crucial aspect for the success of the learning process. She reinforced the socio-educational model of language learning by Gardner and Lambert (1959, 1972), which works with two major motivation orientations for language learning: integrative and instrumental. Integrative motivation is identified with positive attitudes towards the target language group and potential for integrating into that group, or at least an interest in meeting and interacting with members of the group. Integrative motivation refers to a desire to learn a language in order to communicate with people of another culture who speak it and such desire is also there to identify closely with the target language group. Although we refuse here any idea of Nativespeakerism, which again sets the native speaker as a model to be followed, we cannot ignore the personal desire students may have to take part on the group of individuals who are able to speak a language which is world spread due to the development of technology and globalization. Naturally, students may be looking for the language not only for personal satisfaction, but also for interaction. In other words, it has to do with the concept of World English; a language which knows no boundaries and no native speaker. Instead, it belongs to everyone who is motivated enough to 
learn it. Moreover, I believe these aspects go along with some of the key principles of Exploratory Practice (ALLWRIGHT \& HANKS, 2009, p. 149$155)$.

1. Put "quality of life" first

2. Work primarily to understand classroom language learning

3. Work for mutual development

4. Work to bring people together (collegiality)

5. Involve everybody (inclusivity)

6. Make the work a continuous enterprise

7. Integrate the work for understanding into "existing curricular practices" (minimize the burden, maximize sustainability)

Now, I believe it is worth highlighting the importance of collegiality and inclusivity mentioned above taking into account Allwright's assertion "we need the strongest possible collaborative atmosphere among all concerned to make success more likely" (ALLWRIGHT, 2001, p.127)

In summary, the teaching and learning process is all about relationships, especially when we are looking for understanding of a pedagogic phenomenon. Bringing people together is what matters, that is why Systemic-functional linguists who follow Michael Halliday's thoughts in relation to language say that learning a second language is not a mere act of acquiring the language, but a way of creating meaning in a language using the rules to interact. Thus, the teaching/learning process should be meaningful, collaborative and integrative. As far as Allwright's concern about students' "power of veto", it shows that whatever teachers do to deal with any phenomenon or whenever they try to abandon any practice which is apparently not working or even provoking an apparent reaction from learners, they should work for understanding why it is happening by means of monitoring or any other activities which may contribute to help students reflect and express their feelings, thoughts and beliefs. Otherwise, their "power of veto" will keep on frustrating teachers' effort to deal with them. For instance, there is no need to use games or dynamic tasks to cope with monotonous classes without understanding what the classroom practitioners believe to be a monotonous class. Their beliefs may differ due to 
the different experiences they have had throughout their lives.

Instrumental motivation refers to a desire to learn a language because it would fulfill certain utilitarian goals, such as getting a job, passing an examination and so on. This concern has to do with the ESP (English for Specific Purpose) principles as well as System-Functional Linguistics, since both of them consider language as a social practice. To sum up, the basic idea was "tell me what you need English for and I will tell you the English that you need". In other words, it is a purposeful way of teaching and learning. But in fact, these aspects also go along with what Allwright says about relevance and sustainability.

This criterion also arises from bad experience with academic classroom research, but it remains important in the new context created here. First of all it is a matter of people being in charge of their own agendas, instead of allowing themselves to be unduly influenced by the agendas of others (typically from academe) who happen to be in more powerful position (ALLWRIGHT, 2001, p.125)

In short, Allwright defines that whatever is to be the subject of work for understanding or change must be seen to be relevant by those centrally involved. In other words, he acknowledges the protagonism of all classroom practitioners. Their level of interest may depend on the level of relevance of whatever is being proposed.

Therefore, I decided to carry out an investigation in order to try to understand my puzzles in the light of all the previous ideas and perspectives. Together with all classroom practitioners, I want to come to understandings in relation to any possible impact of monotonous classes in the teaching/learning process and check the classroom practitioners' perspective in relation to such phenomenon. I believe Exploratory Practice may contribute to carry out my investigation, help me promote integration with all classroom practitioners and perhaps encourage them to become more critical not only in relation to monotonous classes but any other phenomenon related to the quality of life in the classroom. 


\section{3- METHODOLOGY AND DATA GENERATION}

This chapter aims at reporting and describing the methodological procedures which have been applied in this study. Firstly, I introduce my initial ideas for my research project which rose during the Specialization course. However, after having interacted with my students, I realized I could change some procedures so as to generate data. Secondly, I describe the way all procedures actually took place in the classes when my students and I interacted and cooperated during teaching and learning processes.

\section{1 - RESEARCH PROJECT}

I chose a Qualitative Research approach (RICHARDS, 2003) oriented by Exploratory Practice (ALLWRIGHT \& HANKS, 2009) in order to carry out this research project, whose aim was to investigate monotony in my advanced students' English classes. My research question was focused on the effects of monotony and on the reasons for its occurrence. For this purpose, I started a discussion with a group of English students who studied at an English course in Rio de Janeiro, where I worked.

First of all, I believe it is worth confessing the "Data generating process" that I would have followed if I had not changed my mind. I believe it may show how difficult it is for a researcher to get rid of traditional beliefs. After I have reflected more about my initial traditional ideas, I decided to act differently. I expose how I really acted in order to generate understandings in my classroom.

The "Data generating process" would have followed the steps below:

1. Initial Contact; 2. Arranging consent; 3. First group interview; 4. Transcription; 5. Exploratory teaching; 6. Discussion and 7. Transcription.

Making contact would be essential to make the participants aware of my collaborative intentions and to arrange consent to carry out the research. The first group interview would be carried out with my advanced students and it might work as an instrument to help them reflect about remarkable past experiences when it comes to monotony in the English classes. There were 
some possible questions I could have asked them in the target language:

- Do you remember an astonishing English class that marked your leaning experience?

- Can you talk about it?

- Was the environment pleasant and comfortable (room, desks, technology, peripheral learning)? Why (not)?

- What do students expect nowadays in your opinion?

- How have you come to such a conclusion?

- What about this interview? Is it an activity? How would you classify it, in terms of pleasure, interest, relevance, rhythm or other elements?

The first group interview would be recorded in order to make the transcription easier and practical later on, but I decided not to do it either.

I realized that some narratives in my students' native language would be more useful tools to let them express their points of views, feelings, thoughts and beliefs when it comes to monotonous classes. I thought they would feel more comfortable writing in their native language so I proposed it instead. Thus, they were presented the same questions above, but they were allowed to express their ideas in their native language (Portuguese).

While I was reading Judith Hanks's book Exploratory Practice in Language Teaching, I found in her introduction (Hanks, 2017, p. 3), Dick Allwright's view on Exploratory Practice “[...] a way of getting teaching and learning done so that the teachers and the learners simultaneously develop their own understandings of what they are doing as learners and teachers (2006: 15)", so I realized I could carry out an investigation of my own teaching practices instead of resorting to traditional research methods, such as interviews, that I would have adopted at first

Although, Exploratory Practice may be viewed as a form of practitioner research in which learners as well as teachers are encouraged to investigate their own learning/teaching practices, while currently practicing the target language (Hanks, 2017, p. 3), I learned it should not be adopted just for the sake of doing research, but, instead for understanding events related to classroom life while teaching. I realized that I could interact with my students while carrying out an investigation so as to understand a puzzle of mine. I figured out by reading Hanks' work (2017) that teachers may use their usual teaching/learning activities as ways of investigating their puzzles, contributing 
to help the learning/teaching alone (rather than impeding it because our attention has gone elsewhere). Thus, I concluded that I could use a PEPA (Potentially Exploitable Pedagogic Activity) which is an adaptation made to a classroom activity that would allow students to work with the pedagogic content of the lesson and also explore a reflection upon a specific topic or puzzle. This may contribute to the understanding of what is going on in the classroom. Hanks describes it as follows:

So a PEPA, despite its mysterious acronym, can be something quite simple, mundane even. Above all, it is a familiar classroom activity. It is about taking something so familiar that it is almost invisible, and reconfiguring it to consciously examine the classroom practices that are puzzling to us. It is about using our practices to access the invisible, and to activate our pre-existing acumen (see Iedema et al. 2013) to research our practice. (HANKS, 2017, p. 273)

In short, a PEPA contributes to generate understanding. As there was a moment in which I had to teach modal verbs like "can", "could", "must", "have to", "should" and so on, during some of my classes, a PEPA could be conducted as a tool to understand my students' perspective in relation to monotonous classes. Students were invited to answer some questions on a sheet of paper and the questions were formulated using Modal verbs, since I expected they could exercise the grammatical content as well as reflect critically about their classroom life. The content of the questions dealt with the way students would like their teachers to deliver their classes. These were the questions I asked:

- What can a teacher do to deliver an interesting class for you?

- What could your previous teachers have done in their classes?

- What must / should teachers do to make their classes more entertaining in the future?

The three questions above were put on the board and students were invited to write their answers on a sheet of paper. My intention for writing these 3 questions was to use and to work the modal verbs and my students seemed to have understood the activity and contributed by sharing their ideas 
as well as practicing the content (Modal verbs). After such exploratory teaching, a discussion is relevant in order to reflect on the teaching and learning process and the contribution of each individual to it. Not only will all these procedures contribute to "generate data" but also come to understandings of the fact.

Moreover, in order to have more concrete data for analyses about the issues being investigated here, there was another PEPA which resulted in the preparation of a poster illustrating students' views and reflections about the topic brought into discussion. Therefore, the procedures actually followed the steps below:

1. Reflect and integrate the work for understanding into "existing curricular practices" (grammatical content - Modals) minimizing the burden and maximizing sustainability in my class; 2. Narratives; 3. Discussion and reflection; 4. Exploratory teaching; 5. Discussion and 6. PEPA (poster production) and critical development.

More details will be given in the next section devoted to the "data" generating process.

\section{2 - GENERATING UNDERSTANDINGS}

The data generating process for this study started in 2018. I had an opportunity to define how I would generate data when I was taking the Specialization course. I was about to use a traditional procedure for collecting data: interviews. However, I realized that I could work more for the sake of understanding rather than for the sake of collecting data for my research. I perceived a PEPA (Potentially Exploitable Pedagogic Activity) would contribute to understand my students' perspective when it comes to monotony in their classes, as well as generating data for my research.

In 2018 I was responsible for two groups of students at the English course in Santa Cruz (Rio de Janeiro) where I used to work. One of the groups had English classes on Friday mornings from 08:00 to 10:35 and the students were in their twenties. The other group had classes on Saturday mornings from 10:00 to $12: 35$ and they were about fifteen years old.

Unfortunately, I could not return the analysis to my students because I 
was not working as their English teacher anymore. However, before I left my job, I wanted to promote opportunities in which my students could reflect and become more critical in relation to their classes as well as their learning process while I was working on my puzzle, which I shared with them. After two meetings, I decided to carry out an activity by which they were supposed to express their feelings, thoughts and beliefs concerning a remarkable past experience in an English class. In order to avoid any kind of pressure or embarrassment I proposed a written activity in which they did not have to write their names. I distributed a sheet of paper in which there were several questions in their native language (Portuguese) and they were supposed to write a narrative telling about their experience as English students, either positive or negative. This activity would help me understand more about their beliefs and motivations and perhaps start reflecting about monotonous classes by means of the perspective of those particular groups. In the following illustration, there are the questions my students had to take into account so as to write their narratives about their experience as English students:

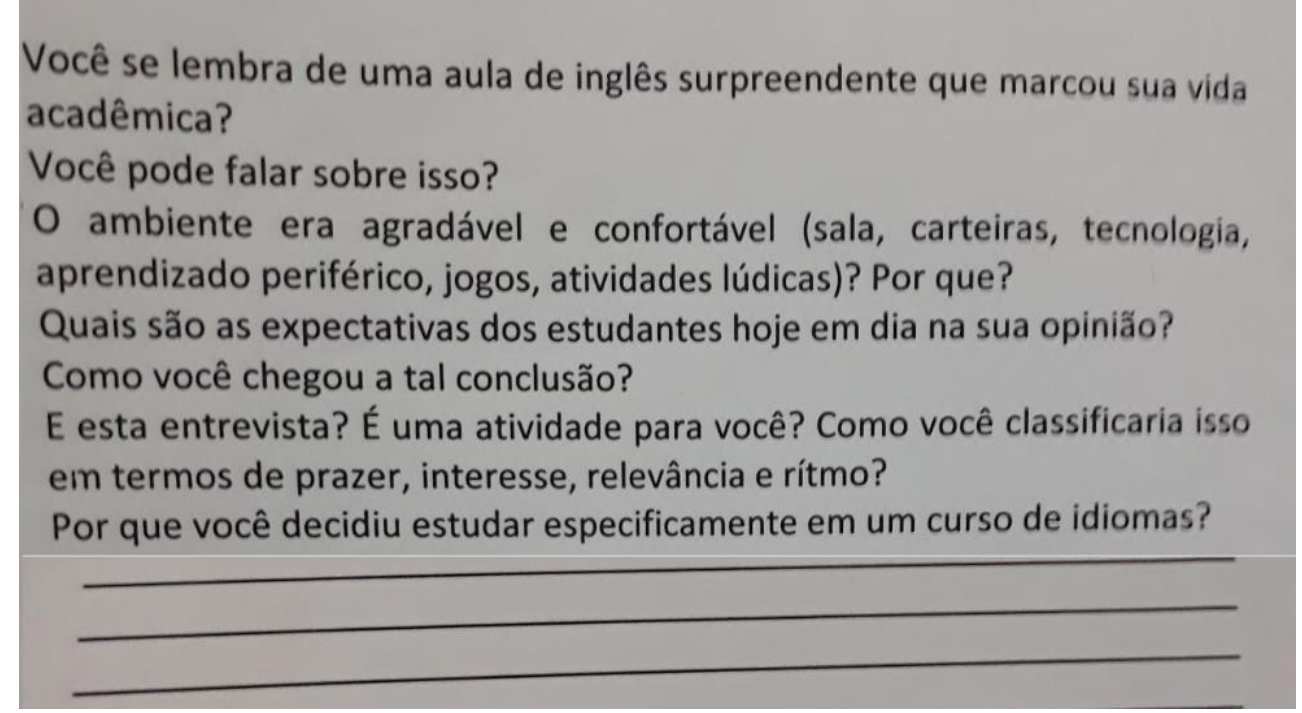

Do you remember an amazing English class that marked your academic life?

Can you talk about it?

Was the environment pleasant and comfortable (room, wallets, technology, peripheral learning, games, ludic activities)? Why?

What are the expectations of the students nowadays in your opinion? 
How did you come to such a conclusion?

And this interview? Is it an activity for you? How would you rate this in terms of pleasure, interest, relevance, and rhythm?

Why did you decide to study specifically in a language course? ${ }^{1}$

I encouraged my students to feel comfortable during the learning process saying that making mistakes is part of the process. After they wrote their narratives, I believed it was time to listen to them. I wanted them to share their experience with the whole group and perhaps have an idea about their beliefs about the "ideal class" as well as monotonous classes. While I was mediating the situation, I realized that some students were able to express out loud their points of view in a critical way, during the discussion. When I read my students' narratives, I also noticed that some of them reflected the criticality of our discussion. In the following section, I will analyze their choice of words in their narratives, which may reflect some of their beliefs in relation to their classes.

For the following class, I had already separated three colored sheets of paper in order to carry out another PEPA. Concerning the sheets of papers, I believed different colors would help my students distinguish the modal verb they would have to use in each paper. On the yellow one, I wrote the following question "What should teachers do to make their classes more entertaining in the future?". Students were supposed to answer the question in order to practice the use of modal verb "should" whereby simultaneously I might understand more about their perspective in relation to the "entertaining class" for the future.

\section{What should teachers do to make their classes more entertaining in the future?}

On the blue sheet of paper, I wrote the following question "What can a

\footnotetext{
${ }^{1}$ Você se lembra de uma aula de inglês surpreendente que marcou sua vida acadêmica? Você pode falar sobre isso?

O ambiente era agradável e confortável (sala, carteiras, tecnologia, aprendizado periférico, jogos, atividades lúdicas)? Por que? (My translation)

Quais são as expectativas dos estudantes hoje em dia na sua opinião?

Como você chegou a tal conclusão?

E esta entrevista? É uma atividade para você? Como você classificaria isso em termos de prazer, interesse, relevância e ritmo?

Por que você decidiu estudar especificamente em um curso de idiomas? (My translation)
} 
teacher do to deliver an interesting class for you?" Students were supposed to answer the question in order to practice the use of modal verb "can" whereby simultaneously I might understand more about their perspective in relation to the "interesting class" for the present time.

\section{What can a teacher do to deliver an interesting class for you?}

And on the green sheet of paper, I wrote the following question "What could your previous teachers have done in their classes?". Students were supposed to answer the question in order to practice the use of modal verb "could" whereby simultaneously I might understand more about the impression they had in relation to their classes in the past.

\section{What could your previous teachers have done in their classes?}

All students were invited to write their comments in order to use the modal verbs, which had been the grammatical content of that class, and start a reflection about the beliefs underlying an "ideal class". I thought that monotonous classes could not be viewed as an "ideal class".

I placed the sheets of paper on the board and distributed colored pens for each student to be able to go to the board and write their comments. According to Exploratory Practice principles, such activity could contribute to the understanding of the grammatical topic during that lesson and could promote a reflection about the issue being investigated "monotonous classes". In addition, the activity would contribute to develop practitioners in a way that they could think more critically during the learning process instead of simply memorizing the content for the sake of grammar. My intention was to discuss if we could develop mutual understandings sharing ideas about their expectations, motivations and the quality of life in the classroom.

I planned a class in which we could promote a discussion about their motivations for learning the English language, their previous narratives and their ideas written on the colored sheets of papers. My intention was to understand if my students' comments might be reflecting some traditional principles or concepts when it comes to the ideal English class. After the class was over, I analyzed their production and my students seemed to have 
associated the ideal class to the use of dynamic activities or technological devices.

During a group discussion, a great idea came up. I decided to create a poster for one of the modules of my Specialization course. My intention was to organize the data generated with my students, so that I would transcribe and analyze later on. Such poster worked as a draft for me and I believed it would be an opportunity to develop my own reflections and understandings, even though it would not be available to my students.

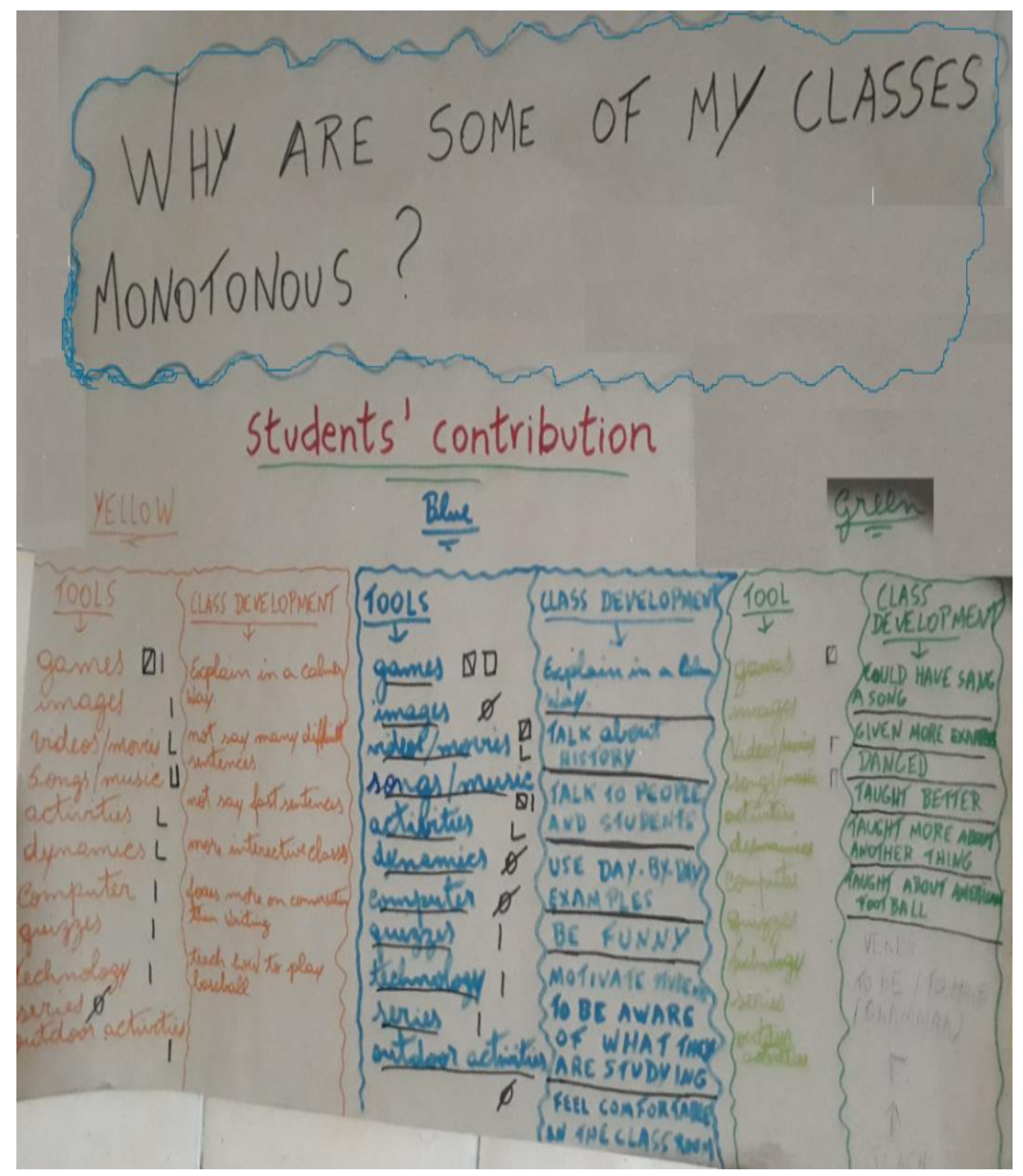

The contents of the poster above are transcribed below. 


\begin{tabular}{|c|c|c|c|c|c|c|c|c|c|c|c|}
\hline \multicolumn{12}{|c|}{$\begin{array}{l}\text { WHY ARE SOME OF MY CLASSES MONOTONOUS? } \\
\text { (STUDENTS' CONTRIBUTION) }\end{array}$} \\
\hline \multicolumn{4}{|c|}{$\begin{array}{l}\text { What should teachers do to } \\
\text { make their classes more } \\
\text { entertaining in the future? }\end{array}$} & \multicolumn{4}{|c|}{$\begin{array}{l}\text { What can a teacher do to } \\
\text { deliver an interesting class for } \\
\text { you? }\end{array}$} & \multicolumn{4}{|c|}{$\begin{array}{l}\text { What could your previous } \\
\text { teachers have done in their } \\
\text { classes? }\end{array}$} \\
\hline Tools & $\begin{array}{l}\text { no } \\
\text { sts }\end{array}$ & $\begin{array}{c}\text { Class } \\
\text { develop } \\
\text { ment }\end{array}$ & $\begin{array}{l}\text { no } \\
\text { sts }\end{array}$ & Tools & $\begin{array}{l}\text { no } \\
\text { sts }\end{array}$ & $\begin{array}{c}\text { Class } \\
\text { develop } \\
\text { ment }\end{array}$ & $\begin{array}{l}\text { no } \\
\text { sts }\end{array}$ & Tools & $\begin{array}{l}\text { no } \\
\text { sts }\end{array}$ & $\begin{array}{c}\text { Class } \\
\text { develop } \\
\text { ment }\end{array}$ & $\begin{array}{l}\text { no } \\
\text { sts }\end{array}$ \\
\hline games & 6 & $\begin{array}{l}\text { explain } \\
\text { in a calm } \\
\text { way }\end{array}$ & 1 & games & 9 & $\begin{array}{l}\text { Explain in a } \\
\text { calm way }\end{array}$ & 1 & $\begin{array}{c}\text { game } \\
\mathrm{s}\end{array}$ & 4 & $\begin{array}{l}\text { Sang a } \\
\text { song }\end{array}$ & 1 \\
\hline $\begin{array}{c}\text { image } \\
\mathrm{s}\end{array}$ & 1 & $\begin{array}{c}\text { Not say } \\
\text { many } \\
\text { difficult } \\
\text { sentence } \\
\text { s }\end{array}$ & 1 & images & 0 & $\begin{array}{l}\text { Talk about } \\
\text { history }\end{array}$ & 1 & $\begin{array}{c}\text { imag } \\
\text { es }\end{array}$ & 0 & $\begin{array}{c}\text { Given } \\
\text { more } \\
\text { examples }\end{array}$ & 1 \\
\hline $\begin{array}{l}\text { Video } \\
\text { s/ } \\
\text { movie } \\
\mathrm{s}\end{array}$ & 2 & $\begin{array}{l}\text { Not say } \\
\text { fast } \\
\text { sentence } \\
\text { s }\end{array}$ & 1 & $\begin{array}{l}\text { Videos } \\
/ \\
\text { movie } \\
\mathrm{s}\end{array}$ & 7 & $\begin{array}{l}\text { Talk to } \\
\text { people and } \\
\text { students }\end{array}$ & 1 & $\begin{array}{l}\text { Vide } \\
\text { os/ } \\
\text { movi } \\
\text { es }\end{array}$ & 2 & Danced & 1 \\
\hline $\begin{array}{c}\text { Songs/ } \\
\text { music }\end{array}$ & 3 & $\begin{array}{l}\text { More } \\
\text { interactiv } \\
\text { e classes }\end{array}$ & 1 & $\begin{array}{l}\text { Songs/ } \\
\text { music }\end{array}$ & 6 & $\begin{array}{l}\text { Use day-by- } \\
\text { day } \\
\text { examples }\end{array}$ & 1 & $\begin{array}{l}\text { Song } \\
\mathrm{S} / \\
\text { music }\end{array}$ & 2 & $\begin{array}{l}\text { Taught } \\
\text { better }\end{array}$ & 1 \\
\hline $\begin{array}{l}\text { activiti } \\
\text { es }\end{array}$ & 2 & $\begin{array}{c}\text { Focus } \\
\text { more on } \\
\text { conversa } \\
\text {-tion } \\
\text { than } \\
\text { writing } \\
\end{array}$ & 1 & $\begin{array}{l}\text { activiti } \\
\text { es }\end{array}$ & 2 & Be funny & 1 & $\begin{array}{c}\text { activi } \\
\text { ties }\end{array}$ & 0 & $\begin{array}{l}\text { Taught } \\
\text { more } \\
\text { about } \\
\text { another } \\
\text { thing }\end{array}$ & 1 \\
\hline $\begin{array}{l}\text { dynam } \\
\text { ics }\end{array}$ & 2 & $\begin{array}{l}\text { Teach } \\
\text { how to } \\
\text { play } \\
\text { baseball }\end{array}$ & 1 & $\begin{array}{l}\text { dynam } \\
\text { ics }\end{array}$ & 0 & $\begin{array}{c}\text { Motivate } \\
\text { students to } \\
\text { be aware of } \\
\text { what they } \\
\text { are studying }\end{array}$ & 1 & $\begin{array}{l}\text { dyna } \\
\text { mics }\end{array}$ & 0 & $\begin{array}{l}\text { Taught } \\
\text { about } \\
\text { American } \\
\text { football }\end{array}$ & 1 \\
\hline $\begin{array}{c}\text { compu } \\
\text { ter }\end{array}$ & 1 & - & - & $\begin{array}{c}\text { compu } \\
\text { ter }\end{array}$ & 0 & $\begin{array}{l}\text { Feel } \\
\text { comfortable } \\
\text { in the } \\
\text { classroom }\end{array}$ & 1 & $\begin{array}{c}\text { comp } \\
\text { uter }\end{array}$ & 0 & $\begin{array}{c}\text { Teach } \\
\text { verbs / } \\
\text { grammar }\end{array}$ & 2 \\
\hline $\begin{array}{c}\text { quizze } \\
\mathrm{s}\end{array}$ & 1 & - & - & $\begin{array}{c}\text { quizze } \\
\mathrm{s} \\
\end{array}$ & 1 & - & - & $\begin{array}{c}\text { quizz } \\
\text { es }\end{array}$ & 0 & - & - \\
\hline $\begin{array}{c}\text { techno } \\
\text { logy }\end{array}$ & 1 & - & - & $\begin{array}{c}\text { techno } \\
\text { logy }\end{array}$ & 1 & - & - & $\begin{array}{l}\text { techn } \\
\text { ology }\end{array}$ & 0 & - & - \\
\hline series & 0 & - & - & series & 1 & - & - & series & 0 & - & - \\
\hline $\begin{array}{l}\text { Outdo } \\
\text { or } \\
\text { activiti } \\
\text { es }\end{array}$ & 1 & - & - & $\begin{array}{l}\text { Outdo } \\
\text { or } \\
\text { activiti } \\
\text { es }\end{array}$ & 0 & - & - & $\begin{array}{l}\text { Outd } \\
\text { oor } \\
\text { activi } \\
\text { ties }\end{array}$ & 0 & - & - \\
\hline
\end{tabular}

I decided to divide my students' answers in two different categories: under the category 1 that I named "Tools", there were words that I considered to have some relation to technological devices or entertaining and motivating activities (games, images, videos, songs, dynamics, computer) My organization was based upon the colored sheets of paper I had received from my students. Under category 2, which I named "Class development", there were sentences 
that I considered to be my students' ideas and beliefs related to the quality of life in our classroom (Explain in a calm way, deliver more interesting classes, focus more on conversation than writing, use day-by-day examples, be funny, motivate students to be aware of what they are studying, teach about sports and so on). I also included the number of answers I got for each category, but it was not done for proving any hypothesis based upon recurrent answers to serve as results, as if I had adopted a quantitative approach. Instead, I believed my decision for providing the numbers of answers I got for each category could contribute to the understanding of my students' perspectives when it comes to our classes and to check whether they share similar points of view or not.

In my last class with my students, I reviewed the modal verbs and their functions in order to elicit from the students the suggestive function "should". Then, I invited them to create a poster and sum up the ideas from the previous classes by giving suggestions concerning the quality of life of our classes. The title of the Poster was "A teacher whose class is not monotonous should":

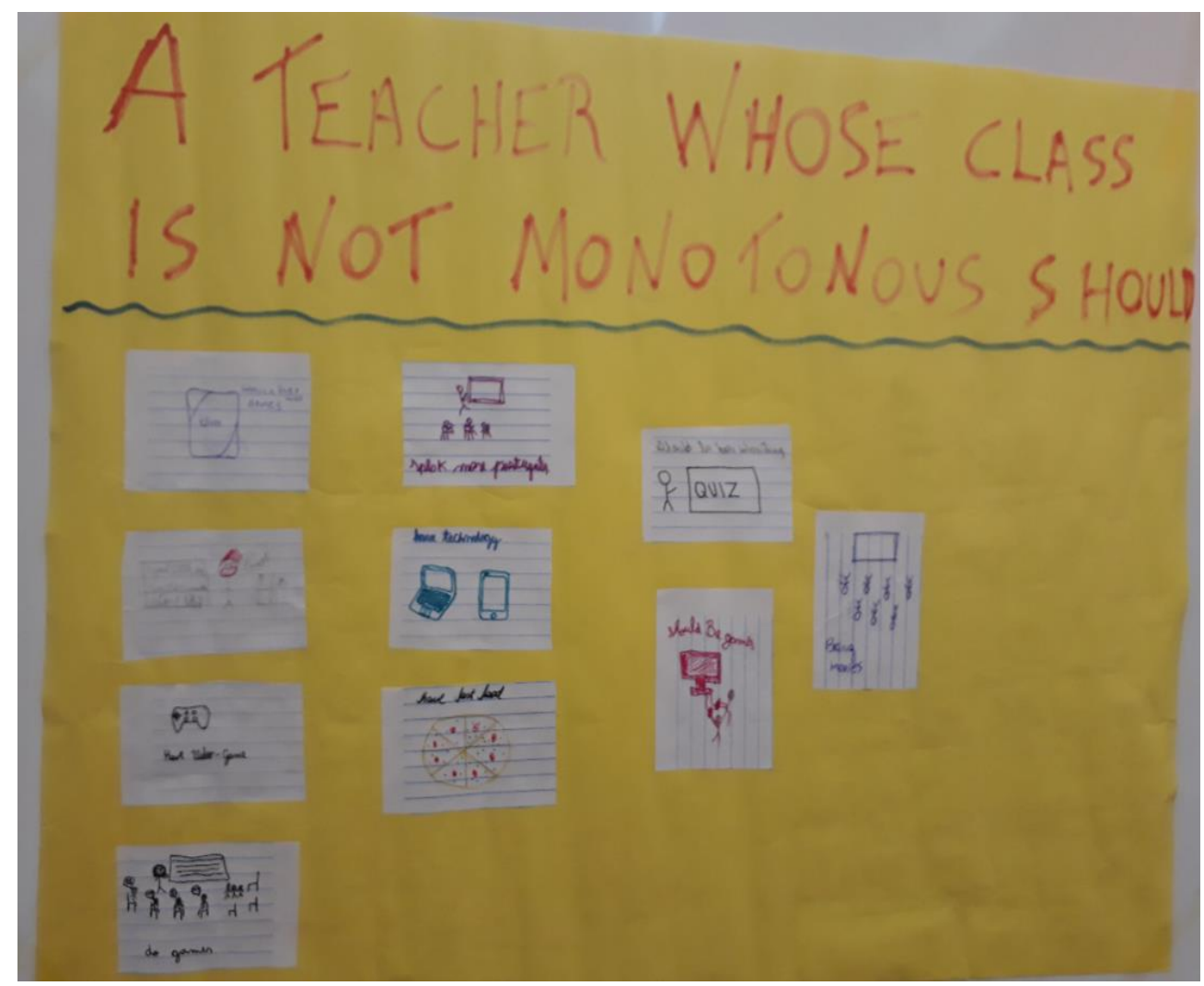

I decided to make the Poster above available because I believed it was part of my process of understanding my students' perspective as well. The contents of the poster above are transcribed below 


\begin{tabular}{|c|c|}
\hline \multicolumn{2}{|c|}{ “A TEACHER WHOSE CLASS IS NOT MONOTONOUS SHOULD...” } \\
\hline Drawing & Description \\
\hline have videogame & $\begin{array}{l}\text { In picture } 1, \text { my student drew a joystick and left } \\
\text { his/her comment expressing that a teacher whose } \\
\text { class is not monotonous should have a } \\
\text { videogame. }\end{array}$ \\
\hline should be games & $\begin{array}{l}\text { In picture } 2, \text { my student drew a TV and two } \\
\text { individuals holding their joysticks and playing } \\
\text { games. S/he left his/her comment expressing that } \\
\text { a teacher whose class is not monotonous should } \\
\text { have games. }\end{array}$ \\
\hline do games & $\begin{array}{l}\text { In picture } 3 \text {, there are students in a classroom in } \\
\text { front of a teacher who stands next to the board. } \\
\text { The teacher has written on the board and the } \\
\text { students seem to be interacting in a group work. } \\
\text { S/he left his/her comment expressing that a } \\
\text { teacher whose class is not monotonous should } \\
\text { have games. }\end{array}$ \\
\hline have technology & $\begin{array}{l}\text { In picture } 4 \text {, there is a notebook and a } \\
\text { smartphone. My student left his/her comment } \\
\text { expressing that a teacher whose class is not } \\
\text { monotonous should have technology. }\end{array}$ \\
\hline have fast food & $\begin{array}{l}\text { In picture } 5 \text {, there is a pizza. My student left } \\
\text { his/her comment expressing that a teacher whose } \\
\text { class is not monotonous should have fast food. }\end{array}$ \\
\hline$\frac{q Q Q 1 Z}{\text { be more interesting }}$ & $\begin{array}{l}\text { In picture } 6 \text {, there is a quiz and a teacher who } \\
\text { seems to be mediating the quiz. My student left } \\
\text { his/her comment expressing that a teacher whose } \\
\text { class is not monotonous should be more } \\
\text { interesting, probably by means of quizzes. }\end{array}$ \\
\hline play more games & $\begin{array}{l}\text { In picture } 7 \text {, there is a card game "UNO". My } \\
\text { student left his/her comment expressing that a } \\
\text { teacher whose class is not monotonous should } \\
\text { have opportunities by which they play more } \\
\text { games. }\end{array}$ \\
\hline Bring movies & $\begin{array}{l}\text { In picture } 8 \text {, there is a screen and an audience } \\
\text { who seems to be watching a movie. My student } \\
\text { left his/her comment expressing that a teacher, } \\
\text { whose class is not monotonous, should bring } \\
\text { movies. }\end{array}$ \\
\hline $\begin{array}{c}9 \\
\text { Speak more } \\
\text { Portugues }(\mathrm{e})\end{array}$ & $\begin{array}{l}\text { In picture } 9 \text {, there is a teacher next to the board } \\
\text { who seems to be delivering a class in front of } \\
\text { some students. My student left his/her comment } \\
\text { expressing that a teacher, whose class is not } \\
\text { monotonous, should speak more Portuguese (use } \\
\text { the native language during the classes). }\end{array}$ \\
\hline
\end{tabular}


My students wrote their suggestions on a piece of paper after I had distributed colored pens. They were also asked to make a drawing which could reflect their comments. Their participation impressed me because I wondered if they would find the activity too childish for them. They could write their comments and glue the pieces of paper on the board. They cooperated and overcame my expectation. Most of them suggested again activities which could promote some dynamism or interaction in the classes.

Their suggestions may reflect their beliefs and they might contribute to my investigation when it comes to monotonous classes, the "ideal class" and the idea of motivation. What happens inside the classroom is not absolute, it is unpredictable instead. I will keep on discussing such issues in the following section as well as analyzing the data generated in the light of the chosen theoretical background. 


\section{4- DISCUSSING THEORY AND PRACTICE THROUGH DATA ANALYSIS}

This section presents some of the interpretations reached by working with the data generated in an attempt to connect theory selected for this study to the students' narratives or comments collected during interactive moments (PEPA) with the group of students who contributed to the production of posters.

\section{1 - UNDERSTANDING QUALITY OF LIFE IN THE CLASSROOM}

The act of analyzing my students' narratives contributed to make me reflect about my own practices and beliefs as an English teacher. I realized that there is still a powerful historical paradigm that influences individuals to believe in an ideal organization and configuration of a class.

With the passing of time, there were several changes in society which include the development of technology and globalization. However, if we analyze the classroom setting and even the role of teachers and students nowadays, we may realize that few changes really took place in such environment. We will be able to identify who the teacher is and who the students are simply by entering the classroom and analyzing that there is always an individual assuming the control of the situation, sometimes allowing students to make comments after raising their hands. We may also pay attention to the talking time and the act of transmitting the information in an one-sided way, which reflect what has happened in thousands of years. Although methods and approaches have reviewed and questioned the way classes were delivered, there is still a need to rethink and deconstruct some beliefs which attribute the teacher with the responsibility to "transmit" knowledge and "control" the learning process in the classroom. An analogy is possible if we remember the way people acted in a world without computers or internet, in other words, a world where there were only televisions and radios. The communication was one-sided as if an editor of a news program selected everything he believed was important for an audience who would listen to the TV reporter later on. In other words, it was a world in which the transmission of information still took place 
with almost no audience intervention. It may have reflected even the way the classroom setting was constituted: an environment where teachers still believed their work was to show their knowledge and to convey the information with some participation of the "audience" if necessary. There are even teachers who do not like to be interrupted, to have their ideas ignored or to deal with problematic issues.

Nowadays, due to the development of technology and globalization, a new generation of individuals as well as new ways of learning and interacting tend to be a result of such progress (MOITA LOPES, 2006). Different from those people who were used to listening passively to the other individuals who were responsible for transmitting the necessary information such as the reporter on TV and the teacher in the classroom, the new generations got used to the new tools which enable them to interact. The internet became a tool by which people get involved in and take part in the co-construction of information. In the past, the audience was "passive" on a sofa or on a chair listening to the beautiful message conveyed by another individual with whom they could almost never interact. Now the audience can become participants in the coconstruction of the information because they can make comments on websites regarding any message or even contribute to the sophistication of a piece of information by adding new ideas like in Wikipedia. In sum, it is a new world where there should be negotiation of meaning, exchange of ideas and integration in the process of understanding. This may have affected the new generation of students and their beliefs when it comes to the "ideal English class". It may be naïve to believe that keeping the one-sided way of delivering the classes, transmitting relevant information to students without integrating them in the process of co-construction of ideas would not have any consequence.

Students may idealize a class in which a teacher should play the role of a stand-up comedian or a cheerleader as if a variety of dynamic activities could assure the learning. In addition, if a teacher simply adopts technological devices to convey an impression of modernity without mediating situations in which there is interaction among the classroom practitioners, it is just a matter of changing the medium of transmitting the information. Such a class also requires a comfortable environment for students' intervention, their criticism, their 
participation, their involvement or any other contribution for the coconstruction of knowledge. The act of entertaining as if a teacher was a cheerleader or a stand-up comedian may contribute to create a pleasant environment in which students can feel happy and comfortable to participate, but it does not assure the learning. The unpredictability is one of the main aspects that distinguishes the teaching/learning process. Unpredictability, the control that is never thorough, may give room for vetos and interventions so that the act of planning previously an amazing or entertaining class may work or not when it comes to the teaching/learning process.

Allwright (2001, p. 127) mentions that students may have a sort of "power of veto" over teachers and they may destroy a teacher's attempt to teach well. In other words, if some students block themselves and simply ignore what is happening in the classroom, the teaching/learning process may not flow the way it was supposed to be according to the teacher's expectations. The author encourages teachers to establish a collaborative environment. This also goes along with Gardner's (GARDNER \& LAMBERT, 1972 apud NADA AL RIFAI $^{\mathrm{a}}$, 2010, p. 5216-5218) socio-educational model of language learning when they postulate two major motivation orientations for language learning. One of them is the integrative motivation which reflects learners' desire to learn the language to integrate with the group of speakers who use that language. Thus, learning a second language is all about relationship, involvement and interaction.

For Freire (1973 apud HANKS, 2017, p. 44-45), authentic education does not take place when an individual transmits information to another one, but instead, it happens when an individual shares experience with another person, co-constructing information in interaction.

The role of the educator is not to 'fill' the educate with 'knowledge', technical or otherwise. It is rather to attempt to move towards a new way of thinking in both educator and educatee, through the dialogical relationships between both. The flow is in both directions. (FREIRE, 1973, p. 125 apud HANKS, 2017, p. 45)

Although I consider motivation as key for the likely success concerning the teaching/learning process, what happens inside the classroom is still unpredictable when it comes to students' reaction and teachers' attitudes. That 
is why the attempt to control what happens inside the classroom may not be a priority. The new generation of students who are used to interacting and taking part in the process of co-construction of information may consider a teachercentered class as monotonous. Such monotony may affect the learning process or not. If students have a certain motivation, either integrative or instrumental, monotony may not be a problem for the learning process. There must be a huge amount of students who may have learned English despite having had several monotonous classes throughout their academic lives, but it is worth mentioning that again this is the only a way of problematizing the issue and coming to deeper understandings. To sum up, being motivated may not be enough to assure learning. Instead, providing learning opportunities seem to be a primary alternative when it comes to the teaching/leaning process. This is aligned with Allwright when he says the following words in relation to teaching and learning:

Behind all such thinking is the idea that the best teaching will be the teaching that gets nearest to a one-to-one relationship between what gets taught and what gets learned. My preferred alternative is to suggest that the 'best' teaching (if the notion has any value at all) will be that which generates the most, and the most productive, learning opportunities. (ALLWRIGHT, 2006, p.14 in GIEVE \& MILLER)

Allwright (2001, p. 125) also mentions that learning is a matter of people being responsible for their own agendas. Students should be responsible for their learning process in a way that they fulfill their expectation without much influence of others, concerning what hypothetically might be relevant. In other words, learning should be relevant for the learner. It goes along with what Gardner (GARDNER, R.C. \& LAMBERT, W.E.,1972 apud NADA AL RIFAI $^{\mathrm{a}}$, 2010, p. 5216-5218) postulates about the two major motivation orientations for language learning. The instrumental motivation reflects learners' specific purpose of achieving success for academic or professional reasons. In short, learning a second language is also a purposeful process. However, these ideas contribute to the understanding that students may also view their English classes as monotonous when their expectations are frustrated. Nevertheless, having a goal is not a guarantee to assure learning. Especially due to the number of students who can learn English even when they 
are forced by their parents or even when they do not know why learning the target language is relevant or important for them. I selected 2 narratives which shared some common aspects that made me reflect about the beliefs parents have in relation to "the power of English language to transform lives".

Student's narrative 1

My mother has enrolled me on the course because she thinks I had better know how to speak English. A lesson I will never forget is when we saw Doctor Stranger in English and I understood several things in the film. I want to watch movies and series in English without subtitles one day and travel to other countries. $^{2}$ (my translation)

Student's narrative 2

My parents have enrolled me on the course so that I could learn English which is a very important language and is the most spoken language in the world. At first, I only appreciated painting activities and did not like other things very much, but I wanted to learn it so as to be able to play English games and understand them, now I want to learn English to watch movies and series in the original audio without having to read the subtitles or to watch the actors' interviews and understand what they are talking about. ${ }^{3}$ (my translation)

My students' narratives above show how they attribute to parents the belief that learning the English language may transform their lives. It is possible to understand such ideas when they use the verb phrases "has enrolled" and "have enrolled" (me colocou / me colocaram) which contributes to express a passive posture concerning the decision of studying English and of being enrolled in an English course. They agree that the English language is important and it is spoken all over the world, that is why studying the language

\footnotetext{
${ }^{2}$ Minha mãe me colocou no curso porque ela acha que vai ser melhor para mim saber falar inglês. Uma aula que nunca vou esquecer é quando nós vimos Doutor Estranho em inglês e eu entendi várias coisas no filme. Eu quero um dia ver filmes e séries em inglês sem legenda e viajar para outros países.

${ }^{3}$ Meus pais me colocaram no curso para que eu pudesse aprender inglês que é uma língua muito importante e é a mais falada do mundo. No início eu só gostava das atividades de pintar e não gostava muito das outras coisas, mas eu queria aprender para poder jogar jogos em inglês e entendê-los, agora eu quero aprender para ver filmes e séries no áudio original sem precisar de legendas ou ver as entrevistas dos atores e entender o que eles estão falando.
} 
is the best decision.

I realized that most of the students expressed their perspectives concerning an "ideal class" in which there should be entertaining or motivating activities and technological resources. Their motivation was also related to professional success or personal interests. I analyzed the same narratives of the previous students, words and sentences which convey the meaning of an ideal class in their perspectives.

\section{Student's narrative 2}

My parents have enrolled me on the course so that I could learn English which is a very important language and is the most spoken language in the world. At first, I only appreciated painting activities and did not like other things very much, but I wanted to learn it so as to be able to play English games and understand them, now I want to learn English to watch movies and series in the original audio without having to read the subtitles or to watch the actors' interviews and understand what they are talking about. ${ }^{4}$ (my translation)

\section{Student's narrative 1}

My mother has enrolled me on the course because she thinks I had better know how to speak English. A lesson I will never forget is when we saw $\underline{\text { Doctor Stranger in English and I understood several things in the film. I want to }}$ $\underline{\text { watch movies and series in English without subtitles one day and travel to other }}$ countries. $^{5}$ (my translation)

In both narratives, students mention entertaining activities like drawing, games, movies and series which may reflect their motivations to learn but also how an "ideal class" should be. When they mention "I only appreciated painting activities", "I wanted to learn it so as to be able to play English games"

\footnotetext{
${ }^{4}$ Meus pais me colocaram no curso para que eu pudesse aprender inglês que é uma língua muito importante e é a mais falada do mundo. No início eu só gostava das atividades de pintar e não gostava muito das outras coisas, mas eu queria aprender para poder jogar jogos em inglês e entendê-los, agora eu quero aprender para ver filmes e séries no áudio original sem precisar de legendas ou ver as entrevistas dos atores e entender o que eles estão falando.

${ }^{5}$ Minha mãe me colocou no curso porque ela acha que vai ser melhor para mim saber falar inglês. Uma aula que nunca vou esquecer é quando nós vimos Doutor Estranho em inglês e eu entendi várias coisas no filme. Eu quero um dia ver filmes e séries em inglês sem legenda e viajar para outros países.
} 
and "I want to watch movies and series in English without subtitles one day and travel to other countries", it means that students may have a belief concerning how meaningful and useful the English language could be for their lives and that there would be an ideal class in which teachers could attempt to fulfill students' expectations. I realized that although some students seem to be passive concerning the decision of studying English or even forced to study the language, they may change their perspectives while they are studying. Throughout their academic lives, their expectations can be broken or not depending on each one's experience.

I selected two other narratives in which each student acknowledges the relevance of the activity and one of them even mentions the opportunity provided for some reflection.

\section{Student's narrative 3}

I remember my first classes at the language course in which I was learning my first words in English. It was at YES course and in my classroom there were only students who had never studied English. Everyone had to read and speak English, and that was very funny because no one knew how to speak correctly. The environment was comfortable and teachers were very patient. Nowadays, students want to learn how to master another language as quickly as possible. This is because time is passing faster and faster and people want to be prepared for the challenges in life. Regarding this interview, I found it interesting. I decided to study English because the professional area in which I have been integrated fluency in a second language is viewed as a must, especially English. ${ }^{6}$ (my translation)

\section{Student's narrative 4}

Taking a language course opens doors for us and gives us new

\footnotetext{
${ }^{6}$ Eu me lembro dos meus primeiros dias de aula que eu estava aprendendo as minhas primeiras palavras em inglês. Era no curso YES e todos os alunos eram novos e nunca tinham estudado inglês. Todos tinham que ler e falar em inglês, com isso foi muito engraçado porque ninguém sabia falar corretamente. $\mathrm{O}$ ambiente era confortável e os professores muito pacientes. Os alunos atualmente querem aprender a dominar outro idioma o mais rápido possível. Isso porque o tempo está passando cada vez mais rápido e as pessoas querem estar preparadas para os desafios da vida. Essa entrevista achei interessante. Eu escolhi estudar inglês porque a área que eu escolhi trabalhar necessita muito do domínio do segundo idioma, principalmente inglês.
} 
experiences. This makes us learn more about new cultures and new places. Our expectation is to leave the language course fluent and independent. This activity makes me reflect upon the reason why I am here. Studying this "world" language is not easy, just one class a week. You have to try hard otherwise it is not worthwhile, but for me, only the experience makes all the difference; new friends, new projects. It's fun! I feel progress in my "fluency" thanks to Renan. He is really very good and helped me a lot. My goal is to pursue a performing arts college outside the country, and then to live in Busan or Daegu; so I need to learn such language. ${ }^{7}$ (my translation)

When my students mention "this activity makes me reflect upon the reason why I am here" and "regarding this interview, I found it interesting", I realized my students may have had an opportunity for reflecting which goes along with one of the principles of Exploratory Practice. Work for understanding is a process which includes being aware of what was going on throughout the class and why everything went like that. It is possible to notice how affective aspects (TAVARES, 2014, p. 28-41) made all the difference in the learning process of each student while they narrate their experience. When they mention "That was very funny", "is not easy" and "it is fun", it may indicate how affective aspects have everything to do with the learning process as well. Learning involves not only reason and thoughts, but also affect.

Our choices are almost always purposeful, specially when it comes to narratives in which we tend to select noteworthy events that deserve to be told. In other words, narrating is part of life and it is all about experience (BRUNER, 1997 in MORAES BEZERRA, 2012, p. 59). Living and feeling are as important as thinking and knowing. These ideas go along with also my student's narrative 4:

\footnotetext{
${ }^{7}$ Fazer um curso de idiomas no sabre portas e novas experiências. Isso nos faz aprender mais sobre novas culturas e novos lugares. Nossa expectativa é sair daqui fluente e independentes em relação a isso. Essa atividade me faz refletir o porquê de eu estar aqui. Estudar esse idioma "mundial" sinceramente não é fácil, só uma aula na semana. Você precisa se esforçar senão não vale, mas para mim, só a experiência já vale, novos amigos, novos projetos. É divertido! Sinto um progresso na minha "fluência" em relação ao Renan. Ele é realmente muito bom e me ajudou muito. Meu objetivo é fazer faculdade de artes cênicas fora do país, e depois, morar em Busan ou Daegu e preciso desse idioma.
} 
Student's narrative 4

Taking a language course opens doors for us and gives us new experiences. This makes us learn more about new cultures and new places. Our expectation is to leave the language course fluent and independent. This activity makes me reflect upon the reason why I am here. Studying this "world" language is not easy, just one class a week. You have to try hard otherwise it is not worthwhile, but for me, only the experience makes all the difference; new friends, new projects. It's fun! I feel progress in my "fluency" thanks to Renan. He is really very good and helped me a lot. My goal is to pursue a performing arts college outside the country, and then to live in Busan or Daegu; so I need to learn such language. ${ }^{8}$

When my student mentions above "only the experience makes all the difference; new friends, new projects", s/he takes in consideration not only the importance of what s/he has been learning, but also what s/he has been living such as opportunity to have fun, to make new friends and to develop new projects for life.

However, I was not aware of the importance of both affective and cognitive aspects for the quality of life in my classes (TAVARES, 2014). I was prioritizing the cognitive development of my students and preventing myself from understanding their perspective and how they felt in relation to my classes. I got almost "obsessed" with the use of technological devices as a strategy to bring dynamism into my classes and motivate students. For me, motivated and happy students represented "good teaching" and this could lead to effective and meaningful learning. While I was reading my students' narratives and the poster we have produced in class, I started being aware of some beliefs we shared in relation to an "ideal class".

\footnotetext{
${ }^{8}$ Fazer um curso de idiomas no sabre portas e novas experiências. Isso nos faz aprender mais sobre novas culturas e novos lugares. Nossa expectativa é sair daqui fluente e independentes em relação a isso. Essa atividade me faz refletir o porquê de eu estar aqui. Estudar esse idioma "mundial" sinceramente não é fácil, só uma aula na semana. Você precisa se esforçar senão não vale, mas para mim, só a experiência já vale, novos amigos, novos projetos. É divertido! Sinto um progresso na minha "fluência" em relação ao Renan. Ele é realmente muito bom e me ajudou muito. Meu objetivo é fazer faculdade de artes cênicas fora do país, e depois, morar em Busan ou Daegu e preciso desse idioma.
} 


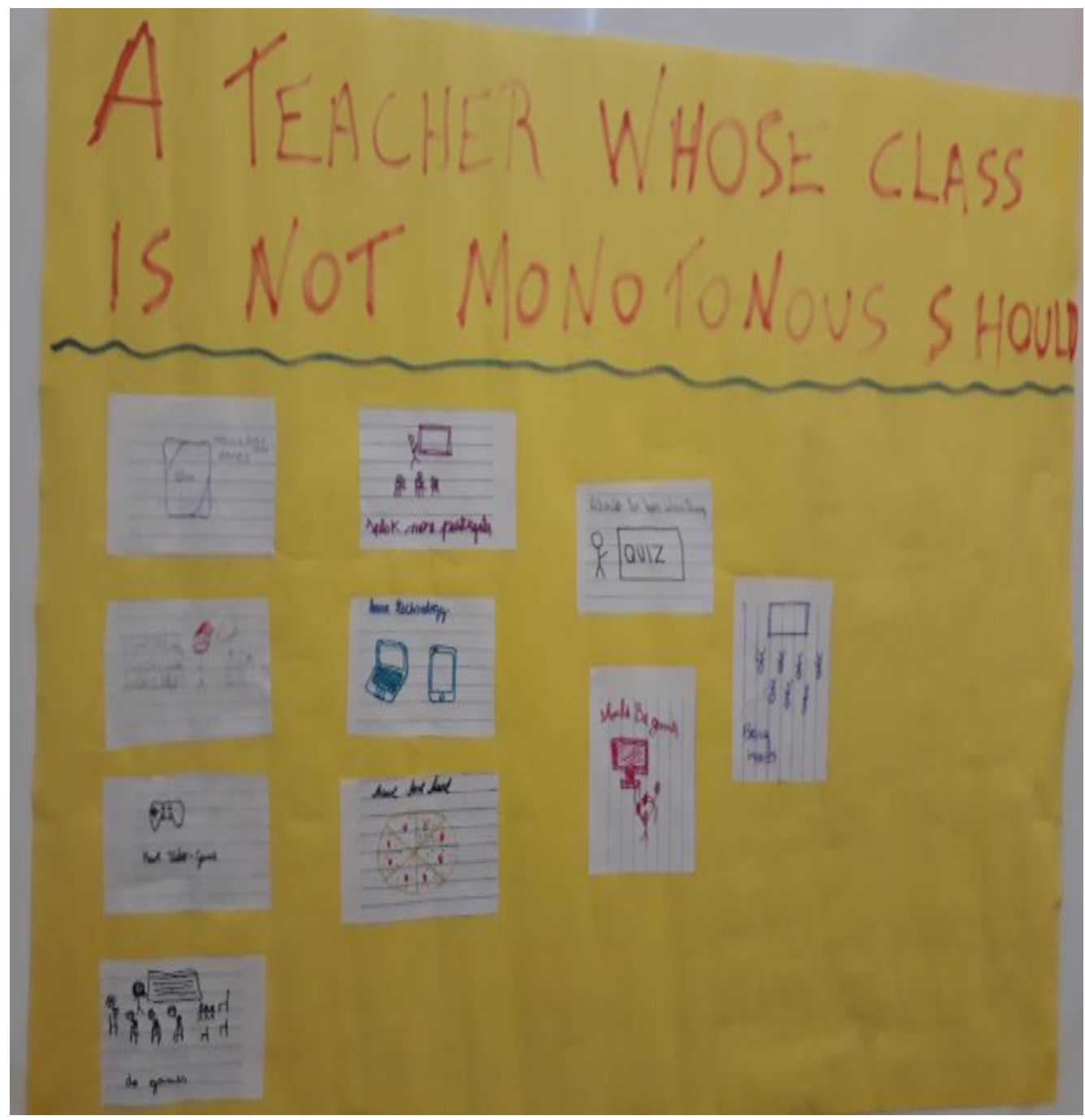

I thought my students' ideas during the poster production (as shown in the above poster) legitimated my attempt to prove the relevance of dynamism in a classroom where motivated students ensured a successful teaching/learning process. Concerning the importance of using techniques to make my classes more effective and meaningful, I selected some of my students' ideas that I believed could bring solutions and improve our classes. By reading some of the principles of Exploratory Practice by Allwright (2003), Miller (2013) and Hanks (2017), I realized that I was more concerned about the quality of my work rather than the quality of life in my classes. In a capitalistic society, there are sometimes individuals involved in the process of education such as teachers, students, parents and so on who still view the learning process as a product that is possible to buy and sell. Therefore, it should be pleasant for those who are involved.

The contents of the poster above are transcribed below. 


\begin{tabular}{|c|c|}
\hline \multicolumn{2}{|c|}{ "A TEACHER WHOSE CLASS IS NOT MONOTONOUS SHOULD..." } \\
\hline Drawing & Description \\
\hline $\begin{array}{l}1 \\
\text { have vider-geme } \\
\text { have videogame }\end{array}$ & $\begin{array}{l}\text { In picture } 1, \text { my student drew a joystick and left } \\
\text { his/her comment expressing that a teacher whose } \\
\text { class is not monotonous should have a videogame. }\end{array}$ \\
\hline should be games & $\begin{array}{l}\text { In picture } 2 \text {, my student drew a TV and two } \\
\text { individuals holding their joysticks and playing games. } \\
\text { S/he left his/her comment expressing that a teacher } \\
\text { whose class is not monotonous should have (be) } \\
\text { games. }\end{array}$ \\
\hline 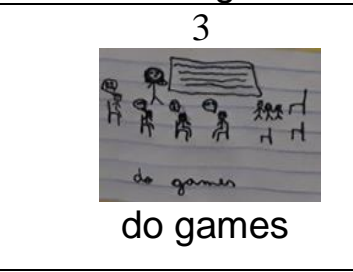 & $\begin{array}{l}\text { In picture } 3 \text {, there are students in a classroom in front } \\
\text { of a teacher who stands next to the board. The teacher } \\
\text { has written on the board and students seem to be } \\
\text { interacting in a group work. S/he left his/her comment } \\
\text { expressing that a teacher whose class is not } \\
\text { monotonous should have (do) games. }\end{array}$ \\
\hline have technology & $\begin{array}{l}\text { In picture } 4 \text {, there is a notebook and a smartphone. } \\
\text { My student left his/her comment expressing that a } \\
\text { teacher whose class is not monotonous should have } \\
\text { technology. }\end{array}$ \\
\hline have fast food & $\begin{array}{l}\text { In picture } 5 \text {, there is a pizza. My student left his/her } \\
\text { comment expressing that a teacher whose class is not } \\
\text { monotonous should have fast food. }\end{array}$ \\
\hline $\begin{array}{c}6 \\
q \text { QUIZ } \\
\text { be more interesting }\end{array}$ & $\begin{array}{l}\text { In picture } 6 \text {, there is a quiz and a teacher who seems } \\
\text { to be mediating the quiz. My student left his/her } \\
\text { comment expressing that a teacher whose class is not } \\
\text { monotonous should be more interesting, probably by } \\
\text { means of quizzes. }\end{array}$ \\
\hline play more games & $\begin{array}{l}\text { In picture } 7 \text {, there is a card game "UNO". My student } \\
\text { left his/her comment expressing that a teacher whose } \\
\text { class is not monotonous should have opportunities by } \\
\text { which they play more games. }\end{array}$ \\
\hline Bring movies & $\begin{array}{l}\text { In picture } 8 \text {, there is a screen and an audience who } \\
\text { seems to be watching a movie. My student left his/her } \\
\text { comment expressing that a teacher, whose class is not } \\
\text { monotonous, should bring movies. }\end{array}$ \\
\hline $\begin{array}{l}9 \\
9 \\
\text { Speak more } \\
\text { Portugues }(e)\end{array}$ & $\begin{array}{l}\text { In picture } 9 \text {, there is a teacher next to the board who } \\
\text { seems to be delivering a class in front of some } \\
\text { students. My student left his/her comment expressing } \\
\text { that a teacher, whose class is not monotonous, should } \\
\text { speak more Portuguese (use the native language } \\
\text { during the classes. }\end{array}$ \\
\hline
\end{tabular}


In pictures 1, 2, 4 and 8, the students wrote that an ideal class should have technology, that is why they drew a joystick, a TV, a videogame, a movie screen, a notebook and a smartphone. They might reflect the belief that an ideal class should have technological devices and entertaining or motivating activities. Probably, my students are used to entertaining themselves by means of such free time activities.

Among all pictures, pictures 3 and 9 may be viewed as pedagogical ideas proposed by my students. Concerning picture 9, the student may have demonstrated that they can take his/her learning seriously by critically recommending the use of the native language (Portuguese) in our classes. Likewise, in picture 3, the student may have expressed his/her understanding when it comes to the relevance of group work during the teaching/learning process, in order to make the learning process possibly easier for him/her. In both pictures, my students drew a classroom in which a teacher is next to a board delivering a class in front of his/her students but there is a notable difference as well. In picture 3 , there are speech bubbles which indicate that students are given the opportunity to speak and to interact in the classroom, whereas in picture 9, there are no speech bubbles and there is nothing written on the board, which would indicate the teacher's mediation and control during the class.

In picture 6 and 7, the students seem to have proposed activities by which we usually have fun in our everyday life such as a card game called "UNO" or a quiz which is really common on TV game shows.

Finally, in picture 5, the student drew a pizza which has also to do with our free time activities, since ordering a pizza is a common strategy to bring people together, to interact, talk and have fun.

My students' ideas above reflect how we have associated the ideal class with the use of entertaining and motivating activities. However, my contact with Exploratory Practice principles, Critical literacy and by analyzing my students' narratives, I perceived that I used to be blind in relation to my own traditional beliefs. I was still cultivating a technicist view dwelling on effectiveness and efficiency as if it could lead definitely to better teaching and learning (HANKS, 2017, p. 5). My students' answers on the colorful sheets of 
paper during the class in which I was teaching Modal verbs and that I had decided to carry out an activity to make them come to the board and help with the understanding of my puzzle and simultaneously exercising what they have learned, they may contribute even more for the ratification of the previous ideas.
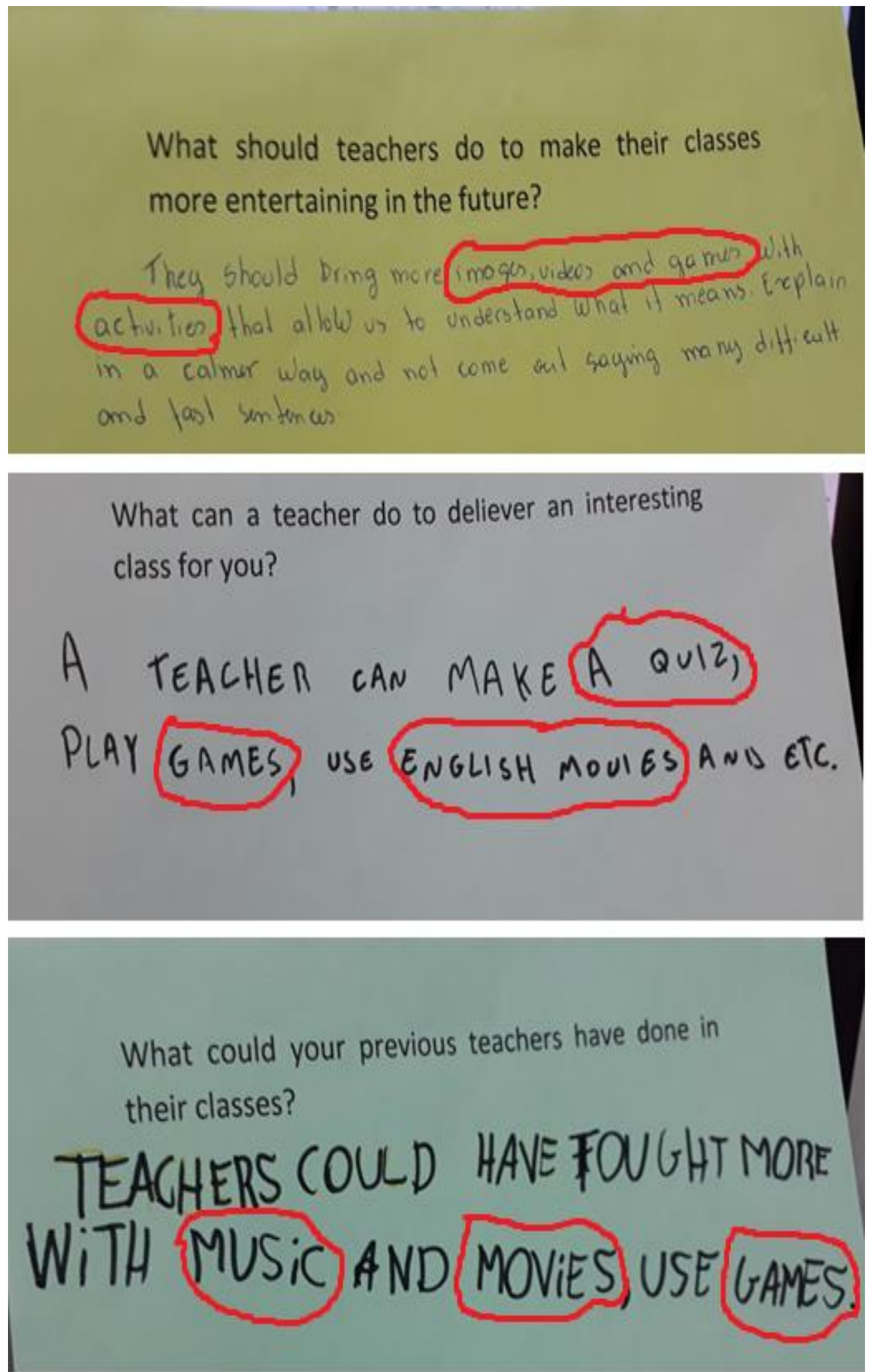
What should teachers do to make their classes more entertaining in the future?

They should bring more images, videos and games with activities that allow us to understand what it means. Explain in a calmer way and not come out saying many difficult and fast sentences.

What can a teacher do to deliver an interesting class for you?

A teacher can make a quiz, play games, use English movies and etc.

What could your previous teachers have done in their classes?

Teachers could have taught more with music and movies, use games.

When my students were asked to exercise the use of Modals, simultaneously they were led to reflect on extra ideas to make their classes more entertaining and interesting. They do not recommend that the teacher stop using grammatical exercises nor even to banish reading and writing tasks. Instead, they just want their classes to reproduce what they live in their everyday lives. Probably, my students do not want their classes to be like a prison where we cannot have contact with the world outside. That is why they attempt to provide ideas which may promote more motivating classes with games, music, movies, funny activities and so on. To sum up, if it is not entertaining, it does not matter for them. 


\section{5- DISCUSSION}

After I had read Exploratory Practice principles, I realized that I could have a different posture during my classes. I used to prioritize the quality of my work and to dwell on the effectiveness of my classes in order to make sure that my students could learn. For me, motivating students by means of dynamic activities, so as to avoid monotonous classes, represented the "ideal class" and I was not able to perceive such traditional way of thinking. I learned that it is possible to carry out a research in my classes without having learners subjected to parasitic, time-wasting research processes. First of all, I was supposed to be more concerned about immediate contributions that my research could bring for all involved in the teaching/learning process instead of worrying more about finding answers for me and my students or even worrying more about the conclusion of my research. This is aligned with some of Allwright's ideas (2019) when he mentions "teachers need to learn how to engage in productive research that contributes to classroom life, rather than constitutes a burden on it". I still viewed my students as clients whose expectations should not be broken. I was not yet aware that research is all about trying to develop understandings rather than to produce generalizable knowledge. I came to know that the "real world" is not reducible to universal facts and such facts are always subject to local conditions. Thus, there is no formula to be the best teacher or even to deliver the "ideal class". Life can be viewed as a sort of continuous research process and it requires considerable local understandings of each context.

Before struggling for changes and questioning how to solve problems in the classroom, we (practitioners of learning) are now according to Allwright (2019) in the realm of teachers and learners realizing that there is something going on in class that they would like to understand better and find a way of using their usual classroom activities to explore their puzzles together.

When my students gave me their narratives that I had proposed as an opportunity for them to think about their experience in relation to the English language and its relevance, I could analyze their motivation and start reflecting about monotonous classes as well as the quality of life in my classes based on their perspectives and beliefs concerning the "ideal class". There were 16 
students who contributed with such investigation sharing their experience by means of their narratives, but I only selected a few of them for practical reasons believing we would not have time to analyze all of them. That is why I only selected those which called my attention. My students provided different reasons for taking English classes: there were students who were influenced by their parents with the excuse that English is important for their lives as a global language. There were also students who decided to learn English as a strategy to cope with entertaining habitual activities like understand songs, movies, games or series. There were students whose motivation was to go on trip and to learn more about another culture. There were also students who expected benefits for learning the English language such as getting a better job, having a tool to help in some academic area and so on. It goes along with what Gardner affirmed concerning "integrative motivation" and "instrumental motivation" reflecting the type of motivation my students may have. Depending whether they have their expectations broken or fulfilled, their performance may be a reflection of what happens in the classroom.

The activities I carried out with my students (PEPAs) made me reflect about their needs or difficulties and think of strategies to understand better the quality of life in the classroom. My intention was that such activities could help my students to become more critical and contribute to understand how they keep on associating good teaching to dynamic activities, but the fact that all activities require interaction contributed to make me come to different understandings. Students also associated good teaching to interaction, in other words, learning is all about socialization, motivation, collaboration, integration and affect. It goes along with the ideas of renowned specialists such as Paulo Freire, Dick Allwright and Gardner.

I believed that I would find in my students' written discourse some proof that may contribute to the understanding that a successful class had everything to do with a variety of activities such as games, videos, movies, songs, technology and other activities whereas, monotonous classes might represent the lack of such activities. Students might have their own motivations to learn the target language and their expectations may reflect their beliefs concerning the ideal English class, which must be completely different from the classes they have at school and as if English teachers were always responsible 
for planning a fantastic class to make students feel happy. In other words, if a teacher is not able to fulfill students' expectations, there will be an impact on the learning process. However, it may be naïve to believe that teachers should always bear the blame when a class appears to be a failure and that a good class plan with a variety of activities would always be the key for avoiding monotonous classes. Most of my students mention the use of motivating activities like games, movies, videos, music, quiz or images, which they believed could facilitate the learning process somehow. But they never recommend that we should abandon traditional teaching activities.

Therefore, there is a need for rethinking the teaching/learning process. The role of a teacher is not merely diffusion of information, especially nowadays when there are tools like the internet doing such job effectively. Teachers should learn how to mediate knowledge without feeling that they are losing their space, prestige or status. Exploratory Practice is an alternative for teachers who want to skip from a world where individuals struggle for solutions and work for controlling what happens inside the classroom such as the learning as a result. Instead, classroom practitioners are supposed to work for mutual understanding and to understand the quality of life in the classroom by means of integration. The aim is actually to develop critical individuals who can discuss any phenomenon or event related to classroom life. By adopting Exploratory Practice principles, I could work not only for understanding my puzzle or my classroom life, but also for the understanding of myself. I could reflect about my posture, my role as a teacher and some conservative beliefs I had. My obsession to motivate my students and my attempt to conceptualize motivation as a key element for learning were deconstructed through such experience. By reading some of Perrenoud's ideas (2002, p. 176 apud MORAES BEZERRA; MILLER; CUNHA 2007, p. 13), I came to understand that the simple presence of the students and their teachers, who are all learners in my opinion, may be indispensable and good enough to achieve success in the teaching/learning process, especially when the classroom practitioners establish an affective relationship so as to develop mutual understandings, produce knowledge, become critical and trust each other.

According to Tavares's work (2014, p. 28-41), our society still keeps some traditional ways of teaching in which teachers hold the knowledge and 
students are like recipients to be filled with information. We tend to prioritize the learners' cognitive development as if the affective aspects, which have also everything to do with the learning process, were merely viewed as accessory facts. Learning is all about relationship, feelings, and emotions, not only thoughts, knowledge and ideas. Affective and cognitive aspects complete themselves and make the learning process more likely to succeed. Thus, the sharing of ideas and the co-construction of knowledge are as important as the development of an affective and trustful relationship with our students. I realized that I was trying to prove that the oppression teachers suffer from pedagogical departments, which demands from them the preparation of motivating classes, the use of technological devices, the domination of teaching techniques, the realization of dynamic activities and so on, was cruel and senseless. Thus, I got "obsessed" with the idea of motivation as an essential aspect which could help teachers deal with monotonous classes and avoid such oppression from the pedagogical departments. I figured out I used to view students as the main protagonists during the learning process. Nevertheless, a classroom is a place where everybody can learn and develop mutual understandings. By focusing exclusively on students and the quality of work, I forgot to consider the quality of life in my classes in which teachers also deserve attention. It may have happened due to my experience as a pedagogic coordinator which contributed to develop a more rational and problem-solving view. The teaching/learning process involves not only cognitive aspects, but also affective aspects (TAVARES, 2014, p. 28-41) and the overall process of education certainly involves several players. Mutual work definitely contributes to optimize the learning process in a classroom just like a theatrical production depends on the work of different individuals who act behind-the scenes. However, if the actor fails at performing well on the stage and frustrates the audience expectations, as a result, the work of all professionals involved in the event may be viewed as a failure as well. Likewise, learning opportunities are created in the classroom which require integration of all classroom practitioners. Without such a collaborative work, both teachers and learners will also fail when it comes to the teaching/learning process (KUMARAVADIVELU, 2003).

Thus, I came to understand that monotonous classes may not represent a 
threat for the learning process. The real threat is preventing ourselves from understanding why any phenomenon happens in the classroom or from understanding the individuality of our students and their needs. Playing the role of protagonist in the learning process has to do with all classroom practitioners. By analyzing my students' contributions (narratives and PEPAs), I understood that my students just do not want their teacher to ignore what they live in their everyday lives. Sometimes, teachers worry more about following a pedagogical department's instructions and conform to standardize their way of delivering their classes. It is possible to affirm that teachers usually wear masks, play the role of actors, behave in a way they do not really want and pretend to be doing a good job in front of their students. As a result, some students react in a way as if they wanted the revelation of their teacher's real identity. They are only longing for a teacher who cares about what they feel and live outside the classroom. Therefore, delivering a class is all about life and disregarding life in the classroom is all about monotony for me. So, monotony could be defined as disregarding learners' "life" in the classroom. Maybe, it is a threat for some language courses or for those who believe classes need to be "dynamic". However, for me, monotonous classes are those which do not integrate the learners' lives with language learning. 


\section{6- FINAL THOUGHTS}

Reflecting upon all these observations, reached by analyzing the data and other references, we may come to an understanding about monotonous classes as a phenomenon which should not simply be ignored or prevented by English teachers. Instead, they are supposed to integrate their students in the process of understanding the quality of life in the classroom. When teachers are encouraged to become explorers themselves in their own classrooms, partly they may increase their overall understanding of classroom language learning and they may improve their learners' chances of making good progress (Allwright; Bailey, 1991, 194-200), that is why Exploratory Practice may contribute to the understanding of monotonous classes as well as any other phenomenon which has to do with the complexity of everyday classroom life. According to Allwright and Bailey, slowly the profession as whole is realizing that, no matter how much intellectual energy is put into the invention of new methods, since what really matters is what happens when teachers and learners get together in the classroom.

There are pedagogical departments of language institutions which still dwell on the accurate application of methods and approaches insisting that it cannot be transgressed because they believe the success of the teaching/learning process depends on that. It is undeniable the contributions of concentrating on planning decisions (what method to use, what sort of syllabus to adopt, and so on), for instance, making teachers play the role of stand-up comedians or cheerleaders in way that they could entertain students and deliver a dynamic classes, but that is not enough to ensure the learning. There are a variety of students who may have had an experience in a monotonous class, but they could learn anyway. The shift of emphasis from working for controlling to working for understanding may contribute to raise awareness when it comes to the unpredictability of what happens in English classes.

Allwright and Bailey acknowledge Gardner's ideas when it comes to motivation affirming "a work in Canada has shown that learners with different type of motivation may display different patterns of interaction in the language classroom and different study habits generally" (Gardner et al. 1976 apud 
Allwright; Bailey, 1991, 182-184). Learners with an "integrative motivation" whose wish is to learn so as to relate better to or integrate with speakers of the target language tended to be much more active in class, volunteering more, making more correct responses and so on. In so doing, they received more positive reinforcement and encouragement than the "instrumentally motivated" learners whose desire was related to academic or professional success which require language fluency. Of course, this is not to say that instrumentally motivated learners cannot be receptive to learning. It is worth reinforcing the essential role of motivation in the learning process since it may be viewed as a key for success. However, again it is not possible to predict precisely what happens in the classroom and how learners can react even though they are motivated somehow. In summary, the idea is to deconstruct the traditional notion that "good teaching" causes "good learning". Allwright affirms students may have a "power of veto" which can make them assume a repulsive posture in relation to any teachers' attempt to integrate them into the learning process. Thus, the act of planning previously a dynamic class is not enough to ensure the learning even though it may entertain students somehow. Considering the fact that students could learn in monotonous classes with the passing of time and the fact that dynamic classes is not a guarantee to ensure the learning, it is possible to reaffirm the enormous complexity of everyday classroom life. In fact, motivation can make all the difference for the learning process, but it would be naïve to simplify such process in this way. Nowadays, a new generation of students who have access to a huge amount of information due to the globalization and the development of technology may be expecting much more than the traditional and one-sided way of "transmitting" knowledge. For instance, if the internet is already playing effectively such role of the diffusion of information all over the world, it would be naïve to believe that the insistence of teachers and pedagogical departments to consider teachers as knowledge holders and students as blank slates would be suitable for the quality of life in the English classroom. Instead, teachers can explore students' schematic knowledge nowadays. Teachers are supposed to play the role of mediators assuming that their students can be integrated in the teaching/learning process by sharing ideas with the all classroom practitioners. It goes along with what Paulo Freire (1970, apud MORGAN, 1997) defends 
concerning the importance of socialization and the reality of each individual for the development of critical thoughts and ideas. By being critical, individuals can learn more about themselves and perhaps transform their contexts. Such perspective contributes to the understanding that, the moment learners enter the classroom, they will never be the same when they leave it.

Nowadays students may expect classes in which they can interact, make interventions and share information in order to integrate new ideas with their background knowledge, so that they may create a new perspective and develop critical thinking. Exploratory Practice may be viewed as an alternative for the development of critical individuals and improve the quality of life in the classroom in which it does not matter how much intellectual energy is put into the invention of new methods or approaches for controlling what happens in the classroom, but instead what matters is to understand any phenomenon which has to do with the classroom practitioners. It does not matter if an English class is dynamic or monotonous when there is no energy put into the understanding of the fact and no attempt to know why the events happened like that. Thus, it is important to focus on the development of the classroom practitioners, integrate them in the teaching/learning process and understand the quality of life in the classroom by means of critical thinking.

Therefore, throughout this investigation it is now possible to affirm that monotony may not exist. In fact, there is a belief of an "ideal class" that each individual may have indicating whether a class is monotonous or not. Classes are not homogeneous for everyone and students' perception in relation to their classes may differ completely. By trying to understand monotonous classes, I could understand myself. I recognized some beliefs I still had. By attempting to conceptualize motivation as a key for students' learning, I could figure out that somehow I was still prioritizing the quality of my work and looking for efficiency. I reflected, and I came to know, that my presence as an English teacher and the relationship with my students are indispensable. It does not matter if we master measures, techniques or the use of technological devices, teachers should focus on the quality of life in the classroom. The quality of life may be viewed as positive or negative, but at least teachers will be able to deal with their students taking into account the context where they can share experience. The learning process is complex and unpredictable, but whenever 
individuals socialize or interact, there may be learning going on. 


\section{7 - REFERENCES}

ALLWRIGHT, D. Planning for Understanding: A New Approach to the Problem of Method. In: Pesquisas em Discurso Pedagógico, Vivenciando a Escola, v. 2, n. 1, p. 7-24, 2003.

ALLWRIGHT, D. Three major processes of teacher development and the appropriate design criteria for developing and using them. In: JOHNSON, B. IRUJO, S. Research and practice in language teacher education: Voices from the field, Minneapolis, MN: Center for Advanced Research on Language Acquisition, p. 115-133, 2001.

ALLWRIGHT, D. Six promising directions in applied linguistics. GIEVE, S; MILLER, I. K. de (Eds.) Understanding the language classroom. Hampshire: Palgrave Macmillan, p. 11-17, 2006.

ALLWRIGHT, D. Exploratory Practice for Continuing Professional Development - an Innovative Approach for Language Teachers. London: Palgrave Macmillan, 2019.

ALLWRIGHT, D.; HANKS, J. The Developing Language Learner. New York: Palgrave Macmillan, 2009.

COOK, G. Applied linguistics. Oxford: Oxford University Press, Chapters 1, 4, 5. 2003.

ELLIS, R. Understanding Second Language Acquisition. Oxford: Palgrave Macmillan, 2003.

FREIRE, P. A importância do ato de ler: em três artigos que se completam. Cortez; 2008.

HANKS, J. Exploratory Practice in language teaching - Puzzling about principles and practices. In: CANDLIN. C. N.; CRICHTON. J. Research and practice in applied linguistics (ed.). London: Palgrave Macmillan. 2017.

KAPLAN, R; GRABE, W. (Eds.) Introduction to applied linguistics. Massachusetts: Addison-Wesley, 1992.

KRAMSCH, C. Culture in foreign language teaching. Iranian Journal of Language Teaching Reasearch. Urmia University Press, v. 2, n. 4, p. 57-78, 2013.

LARSEN-FREEMAN, D. Techniques and principles in language teaching. English Language Teaching. Oxford University Press, v. 58, n. 2, p. 34-35, 2000.

MILLER, I. K. Construindo parcerias universidade-escola: caminhos éticos e questões crítico-reflexivas. In: Gimenez, T.; Góes, M. C. G. (Orgs.). Formação 
de professores de línguas na América latina e transformação social. Campinas, SP: Pontes Editores, 2010.

A prática exploratória na educação de professores de línguas: inserções acadêmicas e teorizações híbridas. In: Silva, Kleber; Daniel, Fátima G.; Kaneko-Marques, Sandra M.; Salomão, Ana Cristina B. (Orgs.). A formação de professores de línguas: Novos olhares - Volume II. Campinas, SP: Pontes Editores, 2013.

MOITA LOPES, L.P. Linguística aplicada e vida contemporânea: problematização dos construtos que têm orientado a pesquisa. In: MOITA LOPES, L.P. (Org.). Por uma linguística Indisciplinar. São Paulo: Parábola, p. 85-87, 2006.

MORAES BEZERRA, I. C. R; MILLER, I. K.; CUNHA, M. I. A. Prática de ensino e Prática Exploratória: oportunidades para buscar compreender a vida no cotidiano escolar". In: FONTOURA, H. A. (Org.). Diálogos em formação de professores: pesquisas e práticas. Niterói: Intertexto, p. 191-213, 2007.

MORAES BEZERRA, I. C. R. Prática Exploratória e a formação inicial do professor reflexivo: "o que vai ficar para os alunos?". Rio de Janeiro: Revista Contemporânea de Educação, n. 13, p. 59-76, 2012.

MORGAN, W. Critical literacy in the classroom - the art of the possible. London: Routledge, p. 1-28, 1997.

OXFORD, Advanced Learner's Dictionary. Oxford: Oxford University Press, 1995.

OXFORD, English Dictionary. Oxford: Oxford University Press, 1989.

RAJAGOPALAN, K. The concept of "World English" and its implications for ELT. English Language Teaching. Oxford University Press, v. 58, n. 2, p. 111117, 2004.

Of EFL teachers, conscience and cowardice. English Language Teaching. Oxford University Press, v. 53, n. 3, p. 200-206, 1999.

RICHARDS, K. Qualitative Inquiry in TESOL. New York: Palgrave Macmillan, 2003.

SCHMITT, N; CELCE-MURCIA, M. An overview of applied linguistics. In: SCHMITT, N. (ed.) An introduction to applied linguistics. London: Arnold, 2002 .

TAVARES, M. R. A relação entre as emoções e os processos cognitivos na aprendizagemà luz do pensamento complexo. São Paulo: the ESPecialist, v. 35, n. 1, p. 28-41, 2014.

TILIO, R. Atividades de leitura em livros didático de inglês: PCN, letramento crítico e panorama atual. Belo Horizonte: RBLA, v. 12, n. 4, p. 997-1024, 2012. 


\section{APPENDICES WITH SOME PRODUCTIONS}

Você se lembra de uma aula de inglês surpreendente que marcou sua vida
acadêmica? Você pode falar sobre isso?

O ambiente era agradável e confortável (sala, carteiras, tecnologia, aprendizado periférico, jogos, atividades lúdicas)? Por que?

Quais são as expectativas dos estudantes hoje em dia na sua opinião? Como você chegou a tal conclusão?

E esta entrevista? É uma atividade para você? Como você classificaria isso em termos de prazer, interesse, relevância e rítmo?

Por que você decidiu estudar especificamente em um curso de idiomas?

Mellapais ane colocaramno curso para que en pudesse aprender ingles que é uma lingua muito importante é a mair fals da de mundo. No inicio en sógos tosa das atividades de pintar e ñäogostava musto dos outres caisars mas en queria aprender para poder jogar

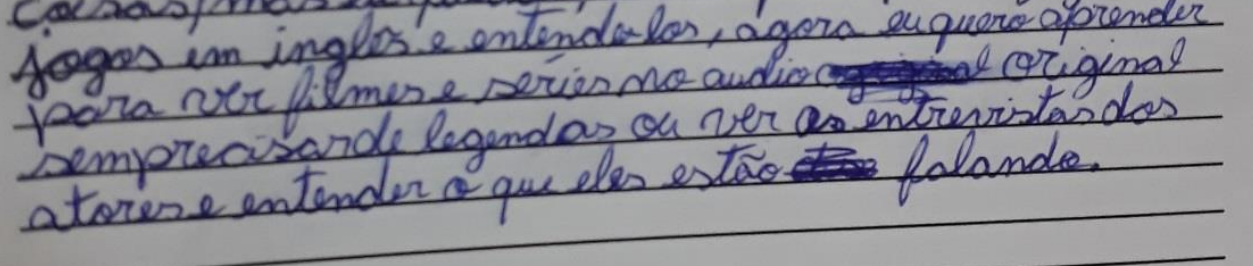
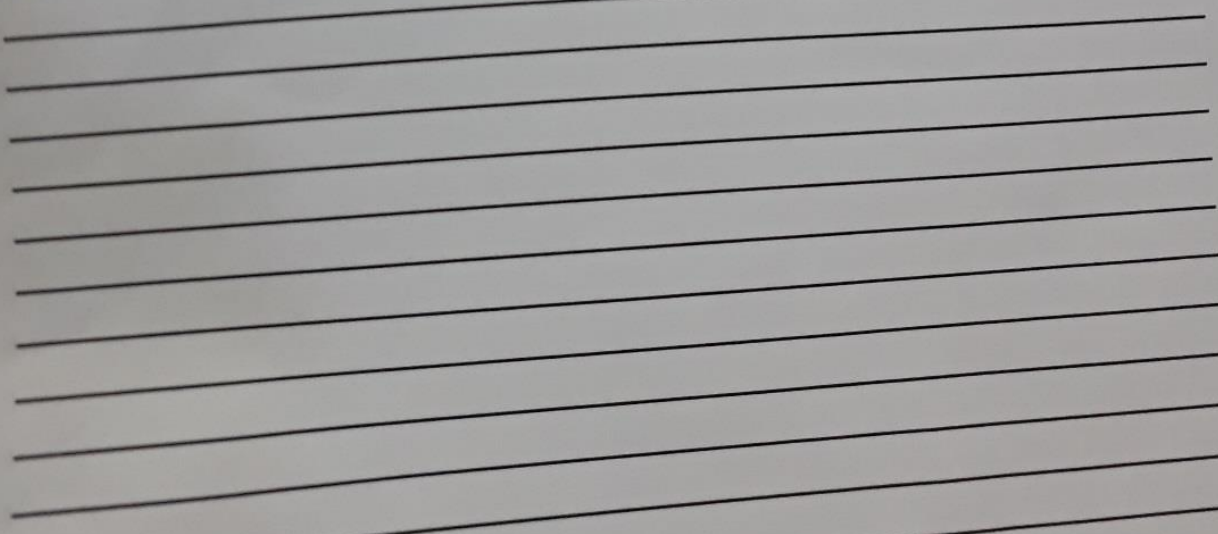

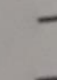

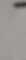

Narrative 1 
Você se lembra de uma aula de inglês surpreendente que marcou sua vida
acadêmica? Você pode falar sobre isso?

O ambiente era agradável e confortável (sala, carteiras, tecnologia, aprendizado periférico, jogos, atividades lúdicas)? Por que?

Quais são as expectativas dos estudantes hoje em dia na sua opinião? Como você chegou a tal conclusão?

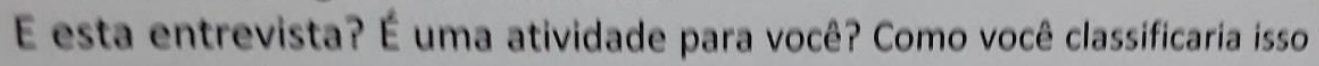
em termos de prazer, interesse, relevância e rítmo?

Por que você decidiu estudar especificamente em um curso de idiomas?

Minhamie me colocaino curpo porque ela acha que bui ber melhor para mim esaker falar inglés. Sma

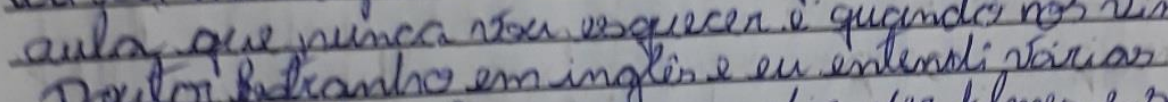

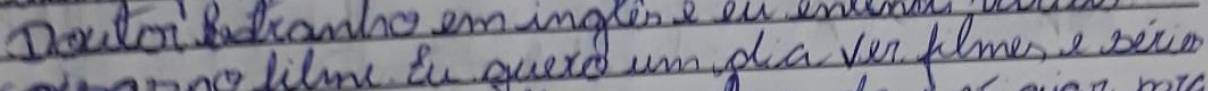

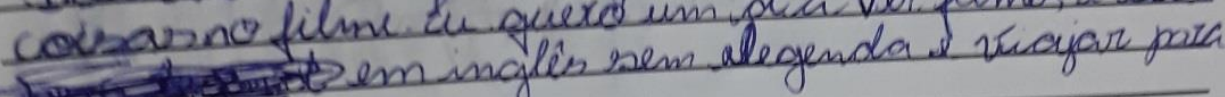

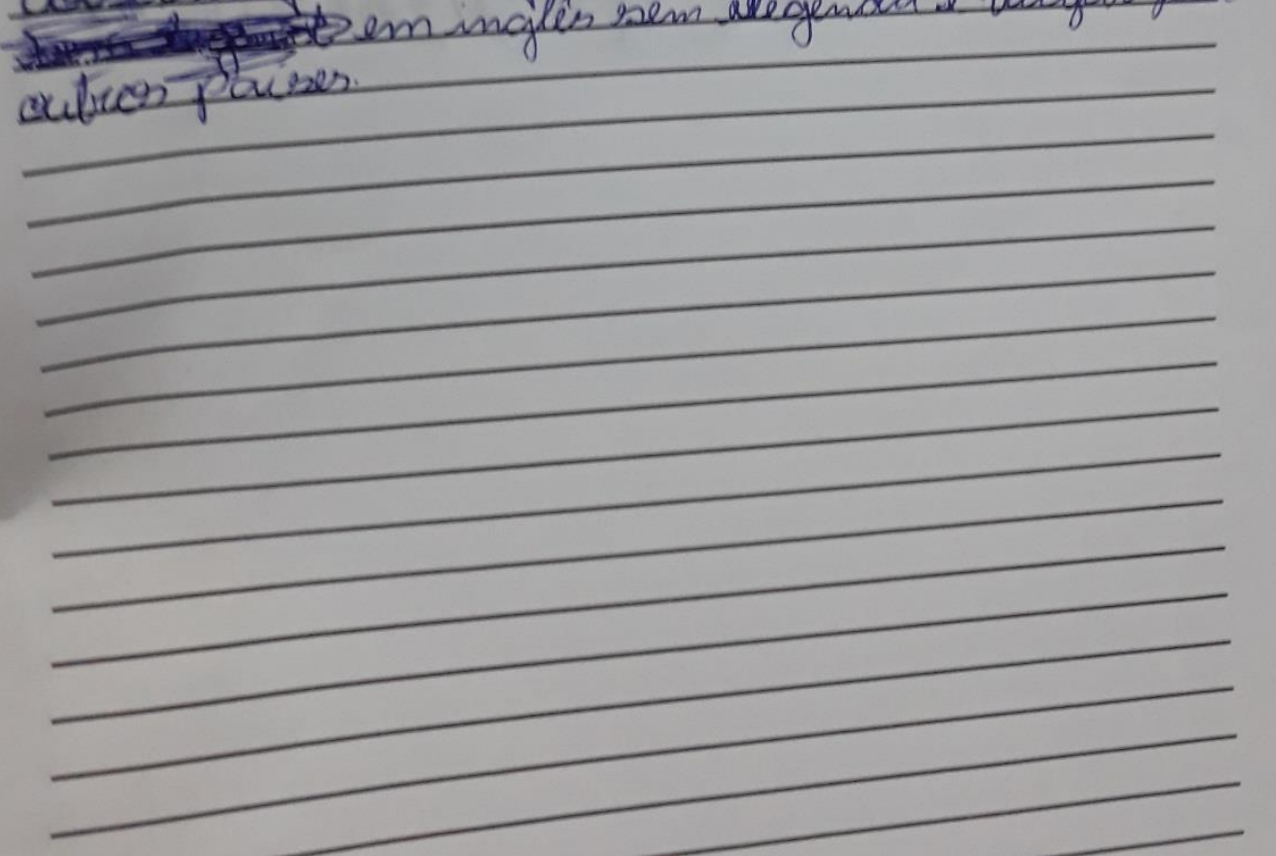

Narrative 2 
Você se lembra de uma aula de inglês surpreendente que marcou sua vida acadêmica?

Você pode falar sobre isso?

O ambiente era agradável e confortável (sala, carteiras, tecnologia, aprendizado periférico, jogos, atividades lúdicas)? Por que?

Quais são as expectativas dos estudantes hoje em dia na sua opinião?

Como você chegou a tal conclusão?

E esta entrevista? É uma atividade para você? Como você classificaria isso ein termos de prazer, interesse, relevância e rítmo?

Por que você decidiu estudar especificamente em um curso de idiomas?

Sasyr um eurso de idiomas nes abre bortas, e movas experiéncias. Jssi mes lay apternder

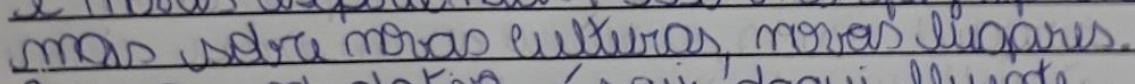
nosa uperctativa ésair daqui fluente

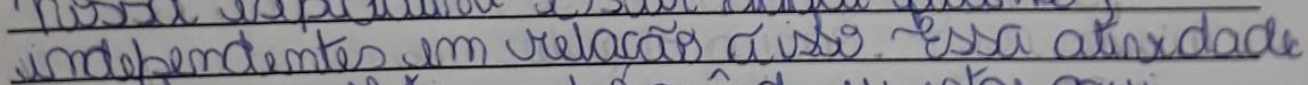

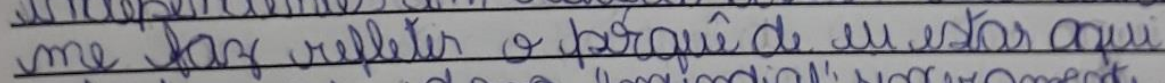
esterdar esse idioma "mindial" senceramente már é lácel sé uma auba ma sumama, necé you cisa se usfircar, semais, náp vale mas, pova mim, sí a experiéncia lá uale, moros amiges, novos pregetos of dinertidi. sinks um progresso ma

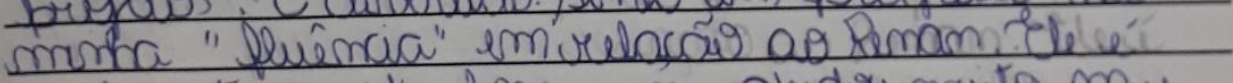
reabmente muitis bom, e me asudier muto. Mue

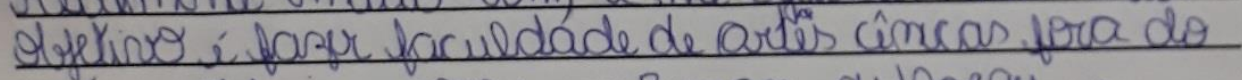
bais, edipois, miror um Bursam, du loaequ, e. presus desolidiona

Narrative 3 
Você se lembra de uma aula de inglês surpreendente que marcou sua vida
cadêmica? Você pode falar sobre isso? aprendizado periférico arável e confortável (sala, carteiras, tecnologia, Quais são as expectativas dos estudantes lúdicas)? Por que?

Como você chegou a tal conclusão? E esta entrevista? É tal conclusão?

em termos de prazer, interesse, para você? Como você classificaria isso Por que você decidiu interesse, relevância e rítmo?

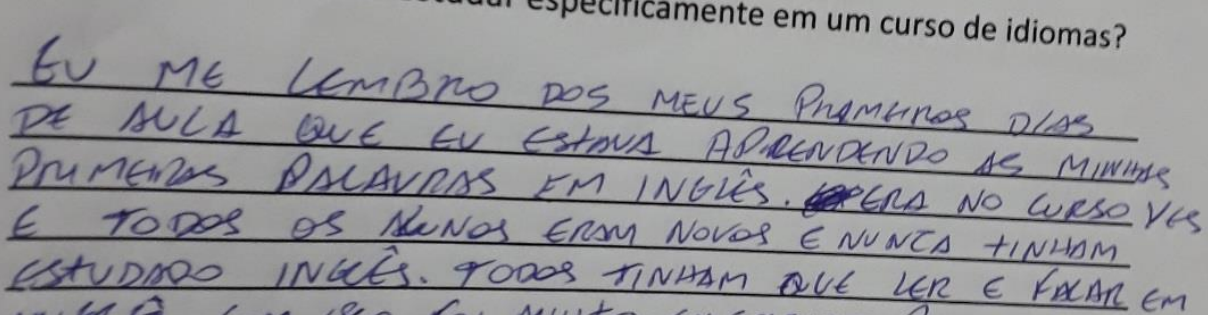
INGLA, COM ise for muito EN GRAGADO Porque NINGUGM SABIA PMAR CORNCAMENTE. D AMBIENTE ERA CONEOTISi os Piofebsones muito Pavientes. OS dund Atuslmente Quenem APrENDER A DOMINIOM OUtho 1010 MA O MAS RÁPIDO

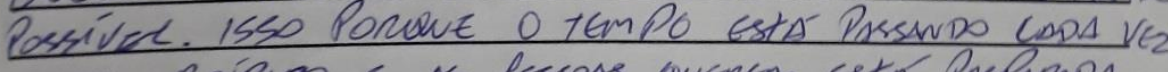

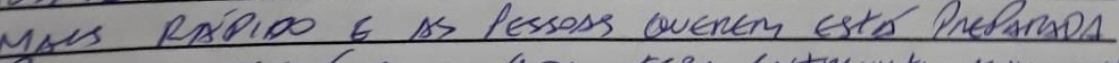

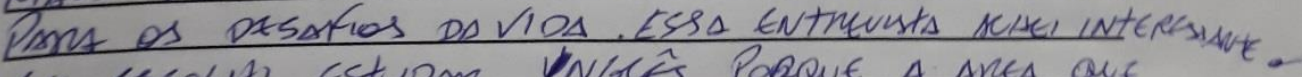
LU Escoliti EStudan YNGLế' PorQuE A AneA OuE

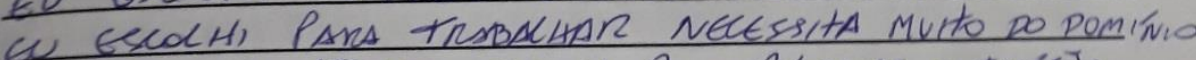
Re SEGUNDS IDIOMA, PNNCIPALMENTE O INGCE'S.

Narrative 4 


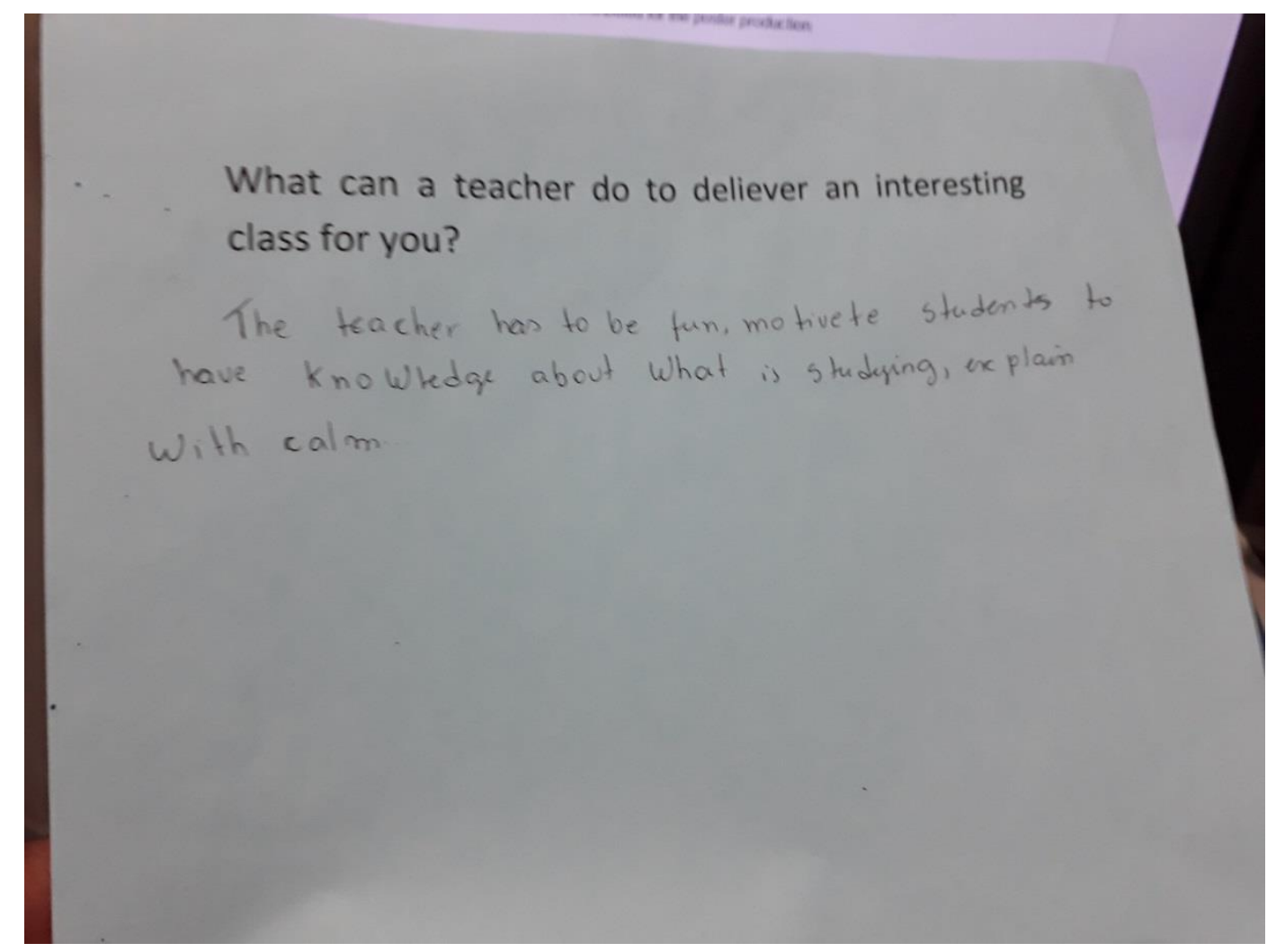

Blue sheet of paper (PEPA) 5A

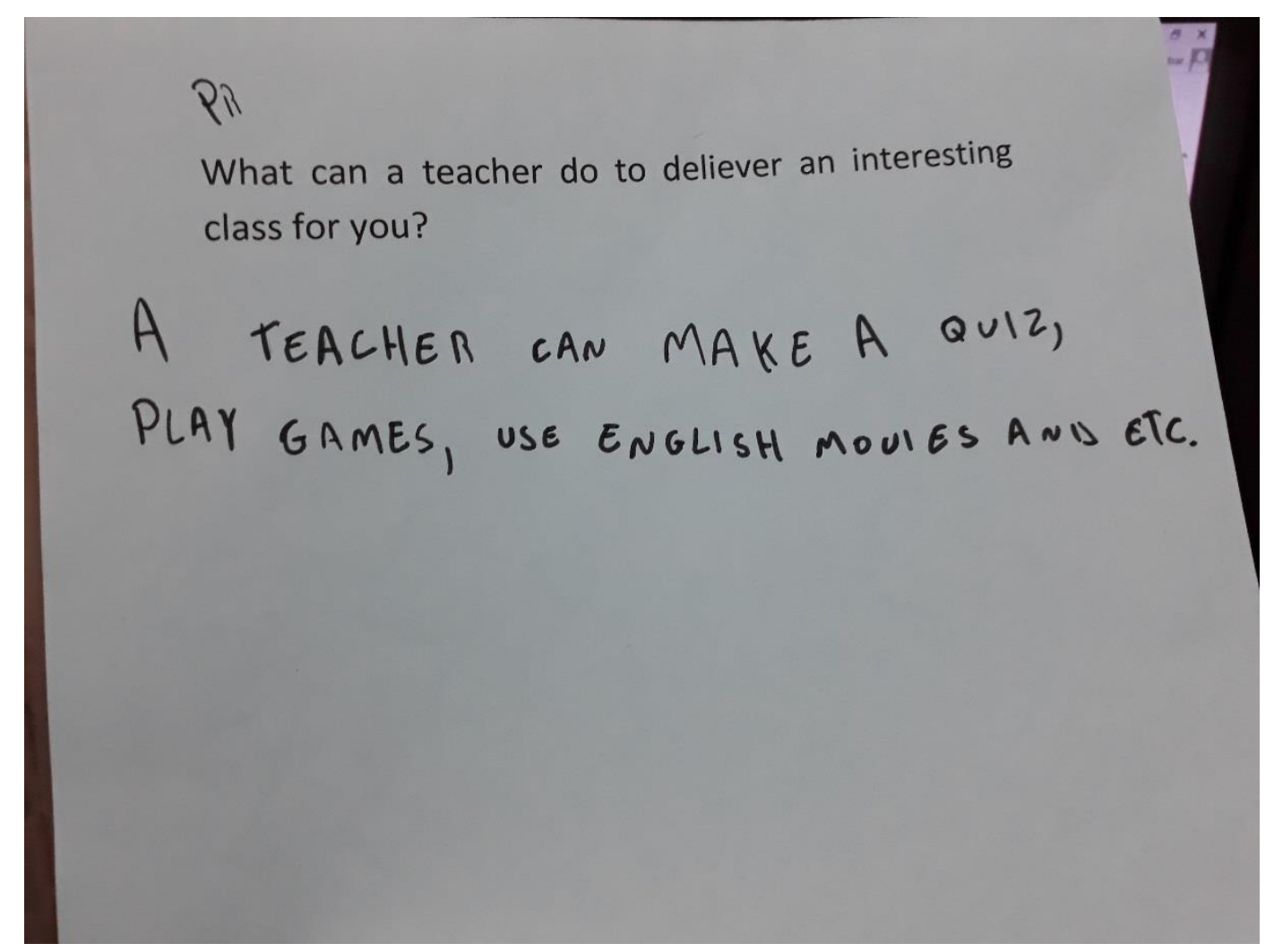

Blue sheet of paper (PEPA) 5B 


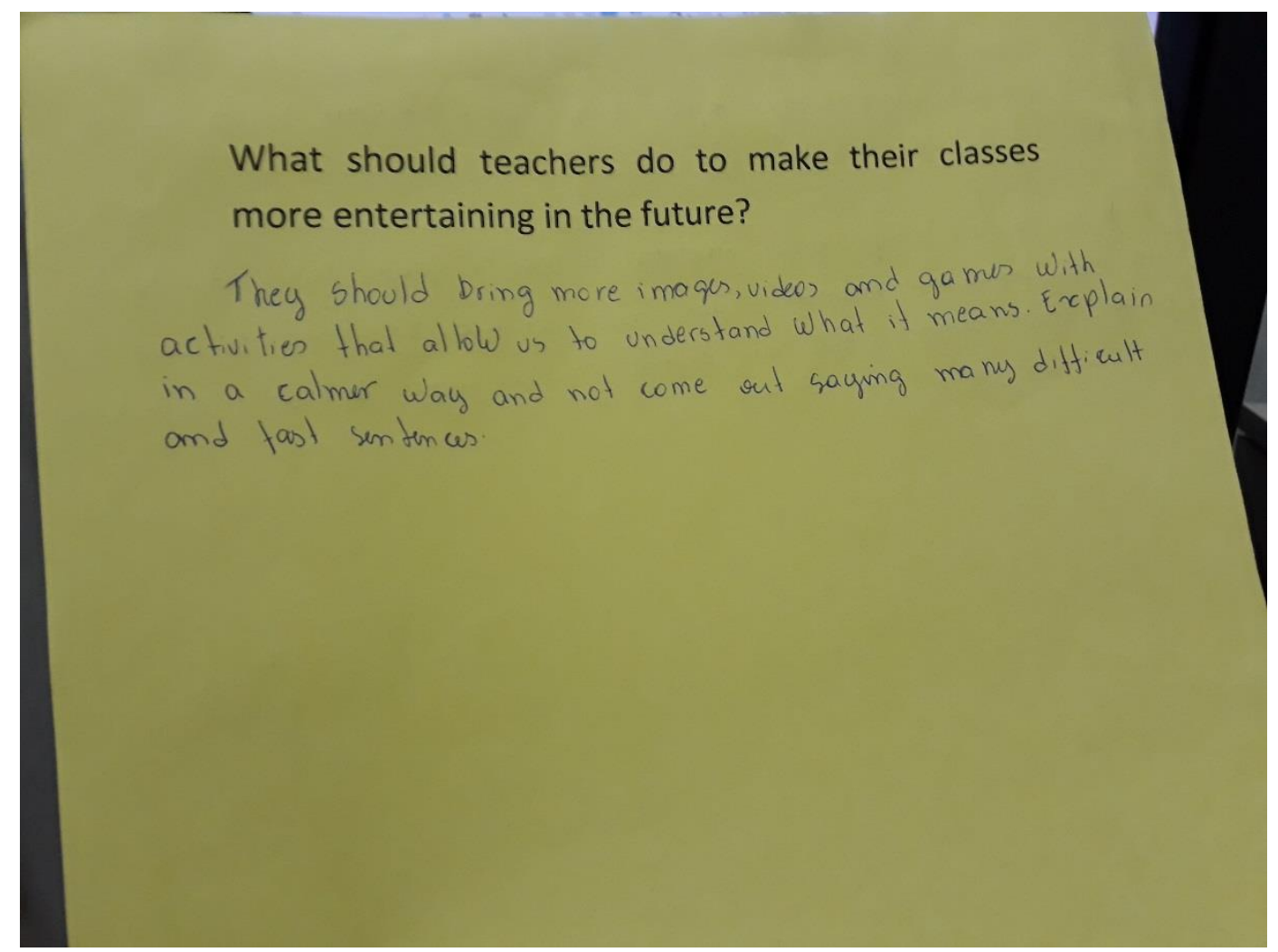

Yellow sheet of paper (PEPA) 6A

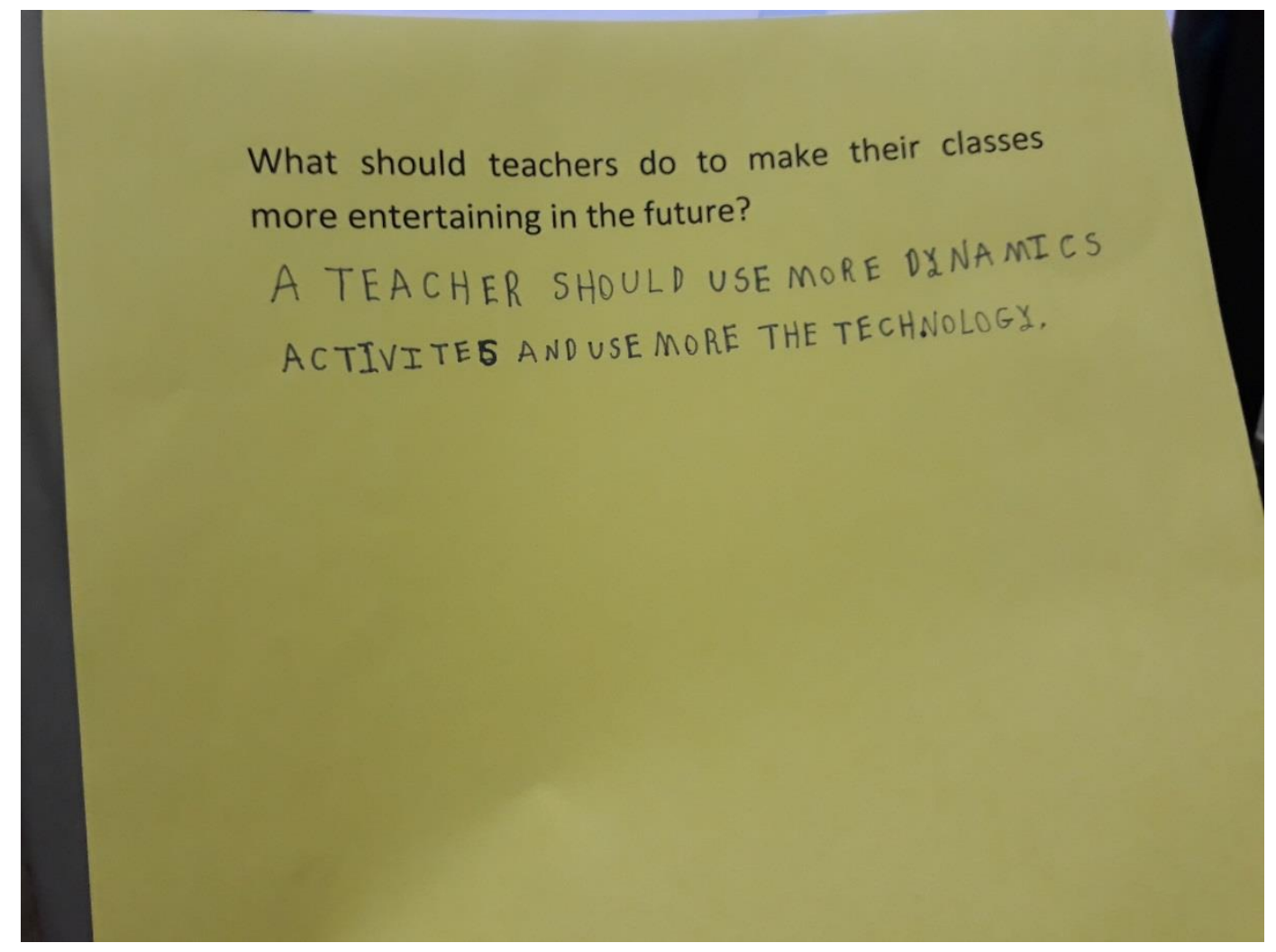

Yellow sheet of paper (PEPA) 6B 


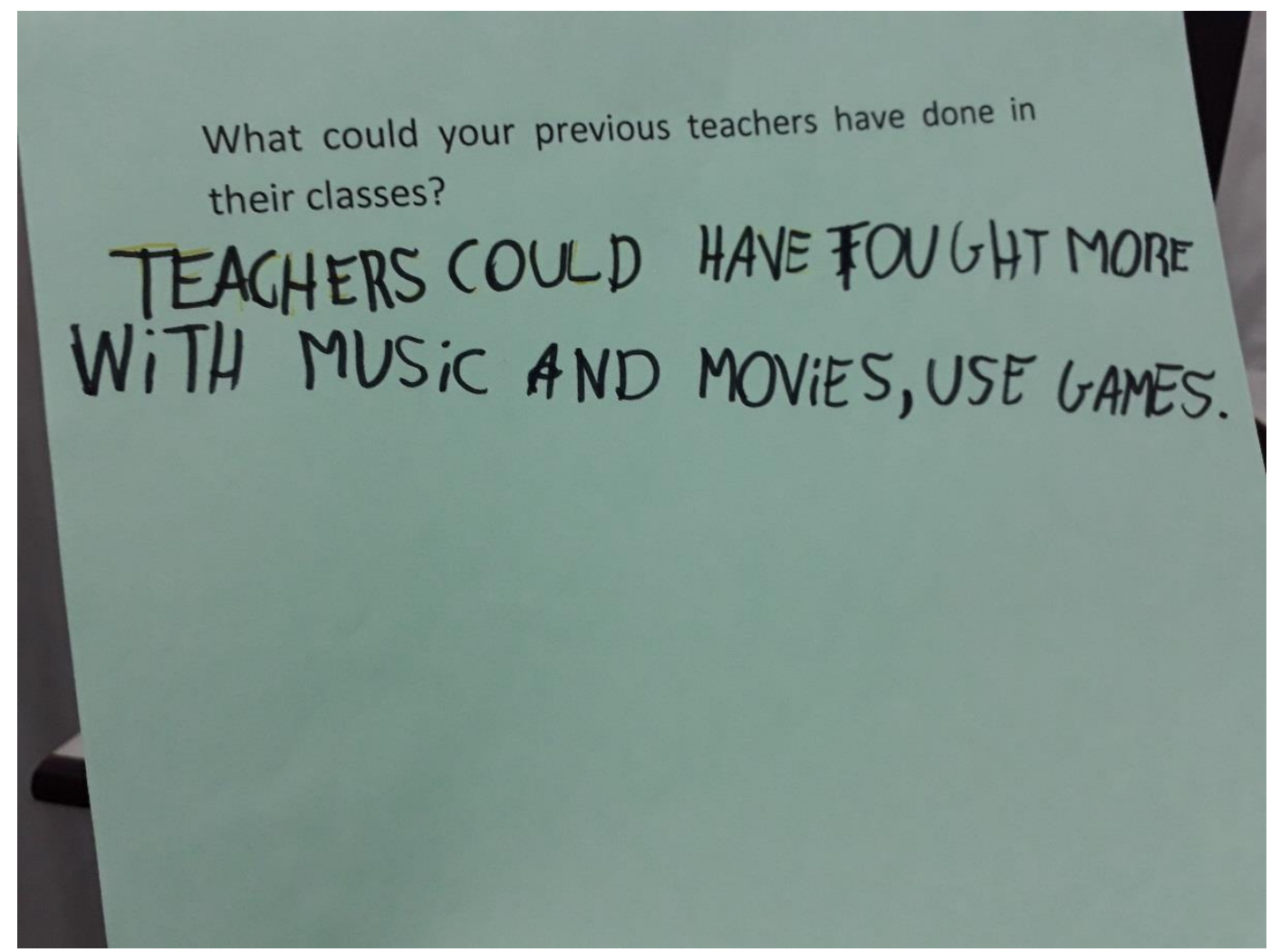

Green sheet of paper (PEPA) 7A

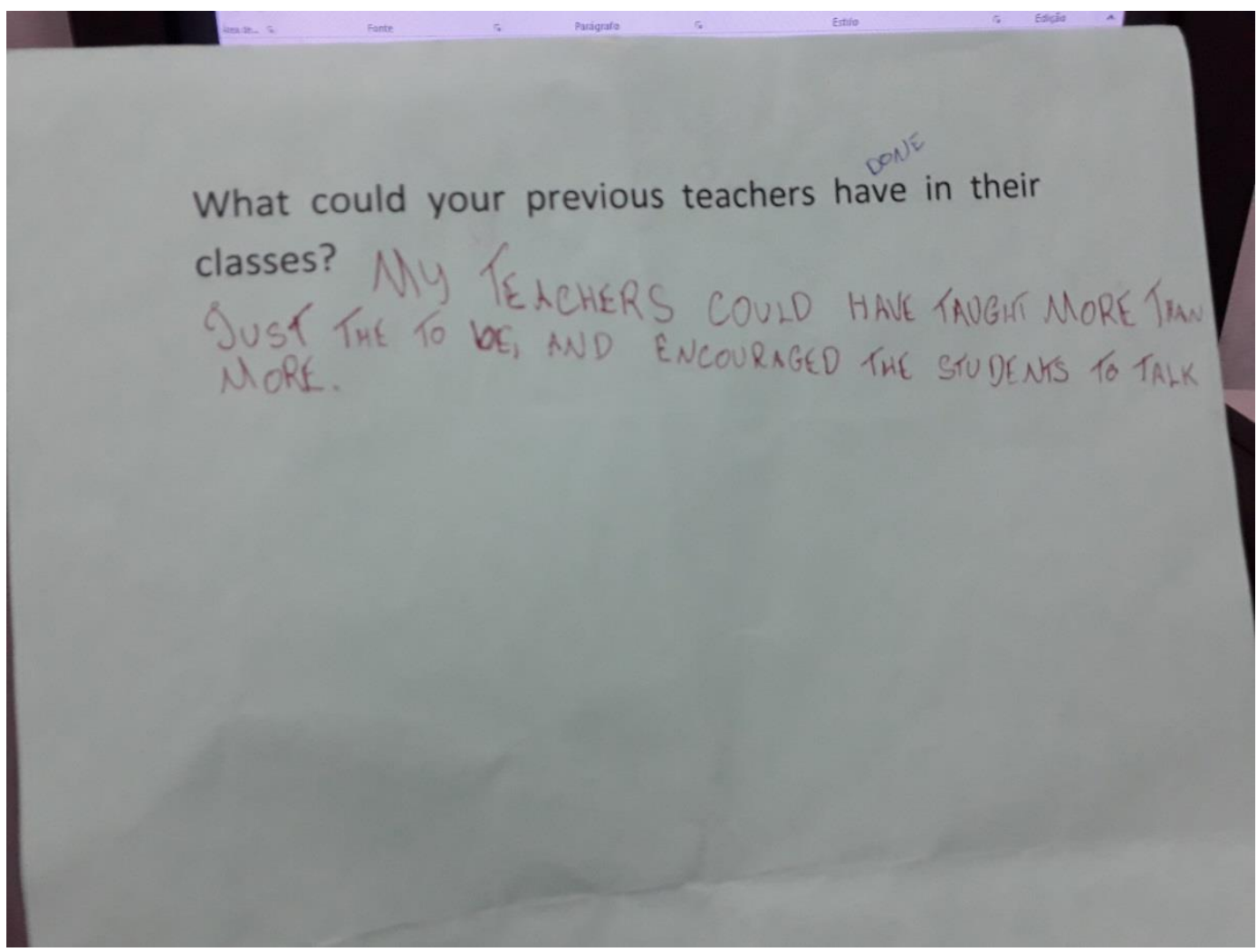

Green sheet of paper (PEPA) 7B 


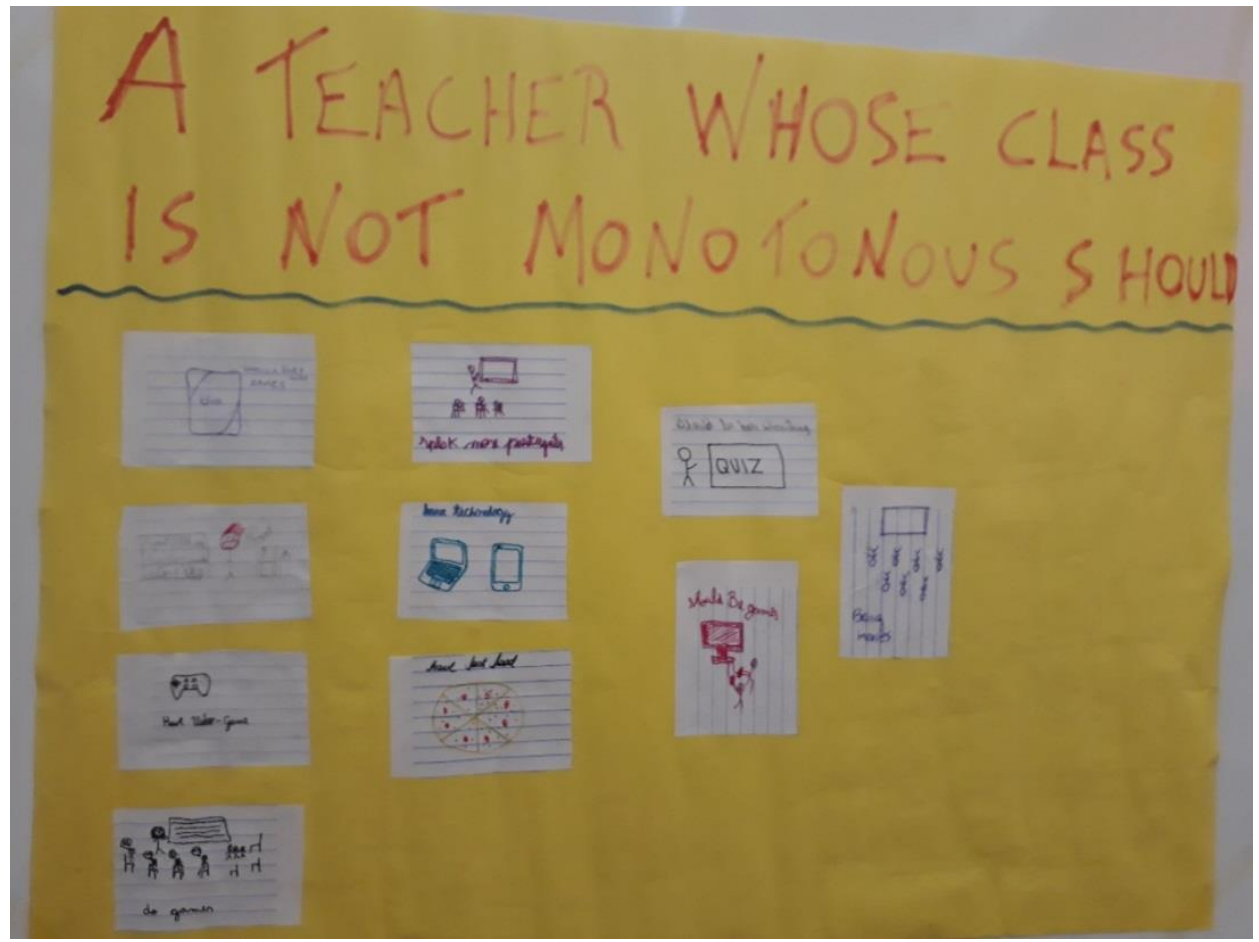

Poster 8A

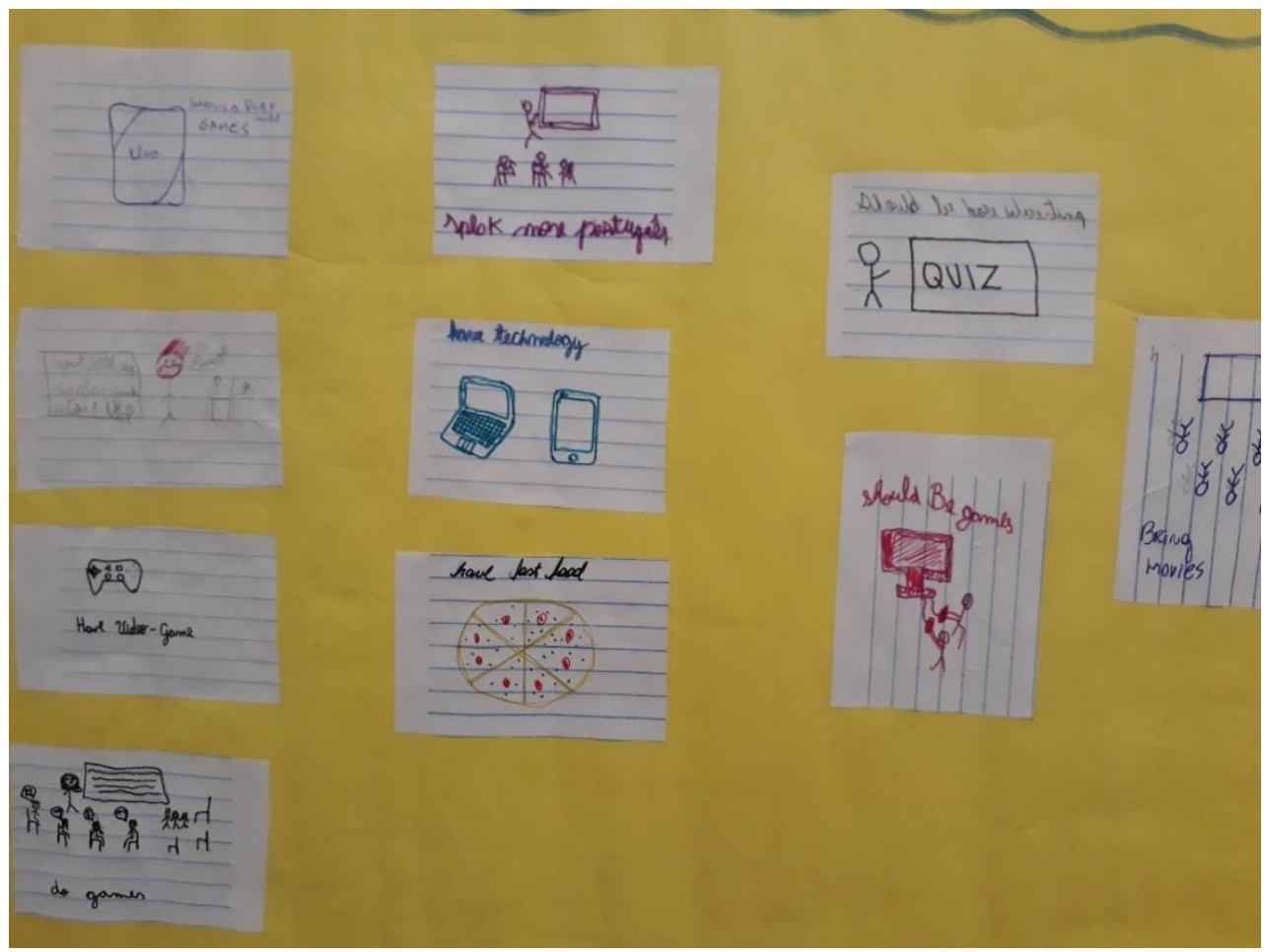

Poster 8 